\title{
The North Anatolian fault in the Sea of Marmara
}

\author{
X. Le Pichon, ${ }^{1}$ N. Chamot-Rooke, and C. Rangin \\ UMR 8538, CNRS, Ecole Normale Supérieure, Paris, France
}

\author{
A. M. C. Sengör \\ Department of Geology, Istanbul Technical University, Istanbul, Turkey \\ Received 7 March 2002; revised 2 July 2002; accepted 30 July 2002; published 2 April 2003.
}

[1] Using the detailed geometry and tectonics of the Main Marmara fault that connects the Gulf of Izmit fault with the Ganos fault established by Le Pichon et al. [2001] and the new GPS data set recently analyzed by Meade et al. [2002], we confirm the existence of a Marmara block delimited to the north by the northern branch of the North Anatolian fault (the Marmara branch) and to the south by the southern branch. The kinematics of this block indicate that the Marmara branch that crosses the Sea of Marmara is close to pure dextral strike slip at a rate of $23 \mathrm{~mm} / \mathrm{yr}$ on its whole length. The short Cinarcik section is the only one where a significant extensional component is predicted. A simple kinematic model accounts for slip partitioning there, with $8-10 \mathrm{~mm} / \mathrm{yr}$ of extension to the south of the basin and $23 \mathrm{~mm} / \mathrm{yr}$ of dextral strike slip along the northern Cinarcik margin. The new GPS data demonstrate the existence of important asymmetric elastic loading along the Main Marmara fault that may have significant implications for the seismotectonics of the area. The expected future large earthquake may rupture the whole main Marmara fault. The partitioning in the Cinarcik basin may produce magnitude 7 normal faulting earthquakes if their repetition time is about 250 years. The 1896 earthquake may have been one of these normal fault earthquakes. The Marmara block is less than $1 \mathrm{Ma}$. Prior to its formation, it was part of the Anatolian block. At this time the Ganos fault was already a dextral strikeslip fault, but the fault system in the Sea of Marmara would have been affected by an extensional component increasing toward the east that accounts for the increasing size of the sedimentary basins eastward. INDEX TERMS: 1206 Geodesy and Gravity: Crustal movementsinterplate (8155); 8010 Structural Geology: Fractures and faults; 8150 Tectonophysics: Evolution of the Earth: Plate boundary — general (3040); 8158 Tectonophysics: Evolution of the Earth: Plate motions — present and recent (3040); KEYWORDS: North Anatolian fault, Marmara, GPS, kinematics

Citation: Le Pichon, X., N. Chamot-Rooke, C. Rangin, and A. M. C. Sengör, The North Anatolian fault in the Sea of Marmara, J. Geophys. Res., 108(B4), 2179, doi:10.1029/2002JB001862, 2003.

\section{Introduction}

[2] Following the $M_{w} 7.41999$ Kocaeli earthquake [Barka, 1999], a major effort was coordinated by the Turkish Scientific and Technological Research Council (Tubitak) to obtain a better estimation of the seismic potential of the North Anatolian fault in the Sea of Marmara. A cruise of the French Ifremer R/V Le Suroit, in September 2000, obtained for the first time detailed bathymetric and high resolution seismic reflection data that, joined to the analysis of previously existing multichannel data [Imren et al., 2001], enabled a careful description of the fault system there. The European Community cofinanced this cruise, part of a French-Turkish bilateral cooperation program. The results of this cruise have been recently

${ }^{1}$ Also at Géodynamique, Collège de France, Paris, France.

Copyright 2003 by the American Geophysical Union. 0148-0227/03/2002JB001862\$09.00 published by Le Pichon et al. [2001]. The reader is referred to this paper for a background on the problem of the North Anatolian fault branch in the Sea of Marmara. Le Pichon et al. [2001] have shown that a single, throughgoing dextral strike-slip fault, the Main Marmara fault, connects the Gulf of Izmit fault, ruptured during the 19997.4 Kocaeli earthquake, with the Ganos fault, ruptured during the 19127.4 Sarkoy-Murefte earthquake (Figure 1). We build on their results and on the detailed analysis of GPS results in the Marmara area by Meade et al. [2002]. We analyze the kinematics of this fault system within the context of the entire North Anatolian fault. We specifically investigate the elastic loading on the Main Marmara fault and discuss the implications for the seismic potential of the Sea of Marmara.

\section{Geometry of the Marmara Fault System}

[3] The Main Marmara fault consists of two segments forming a single throughgoing fault. The western three fourths of the fault (the western segment) is oriented 
ETG 1 - 2 LE PICHON ET AL.: NORTH ANATOLIAN FAULT IN THE SEA OF MARMARA

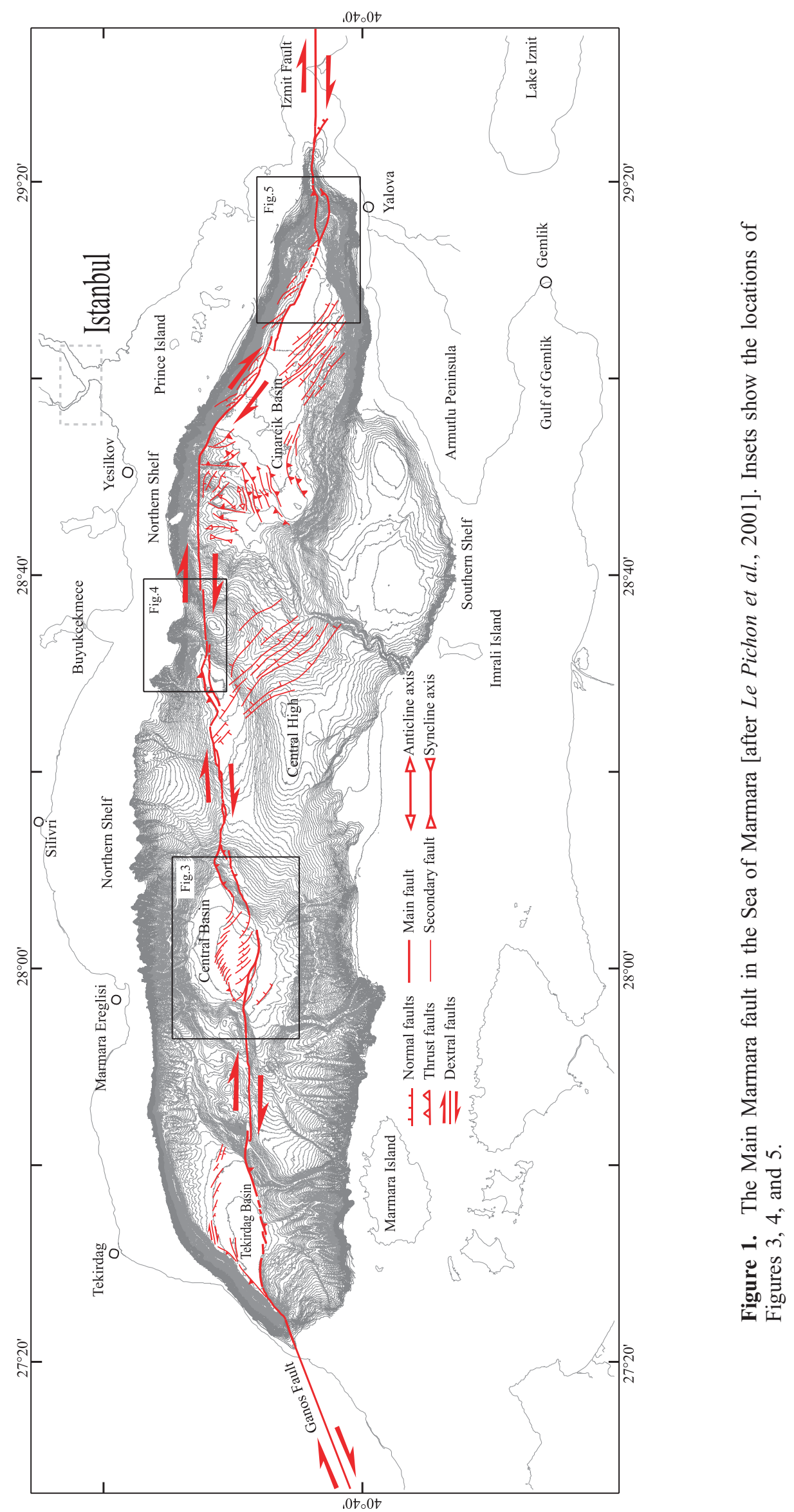




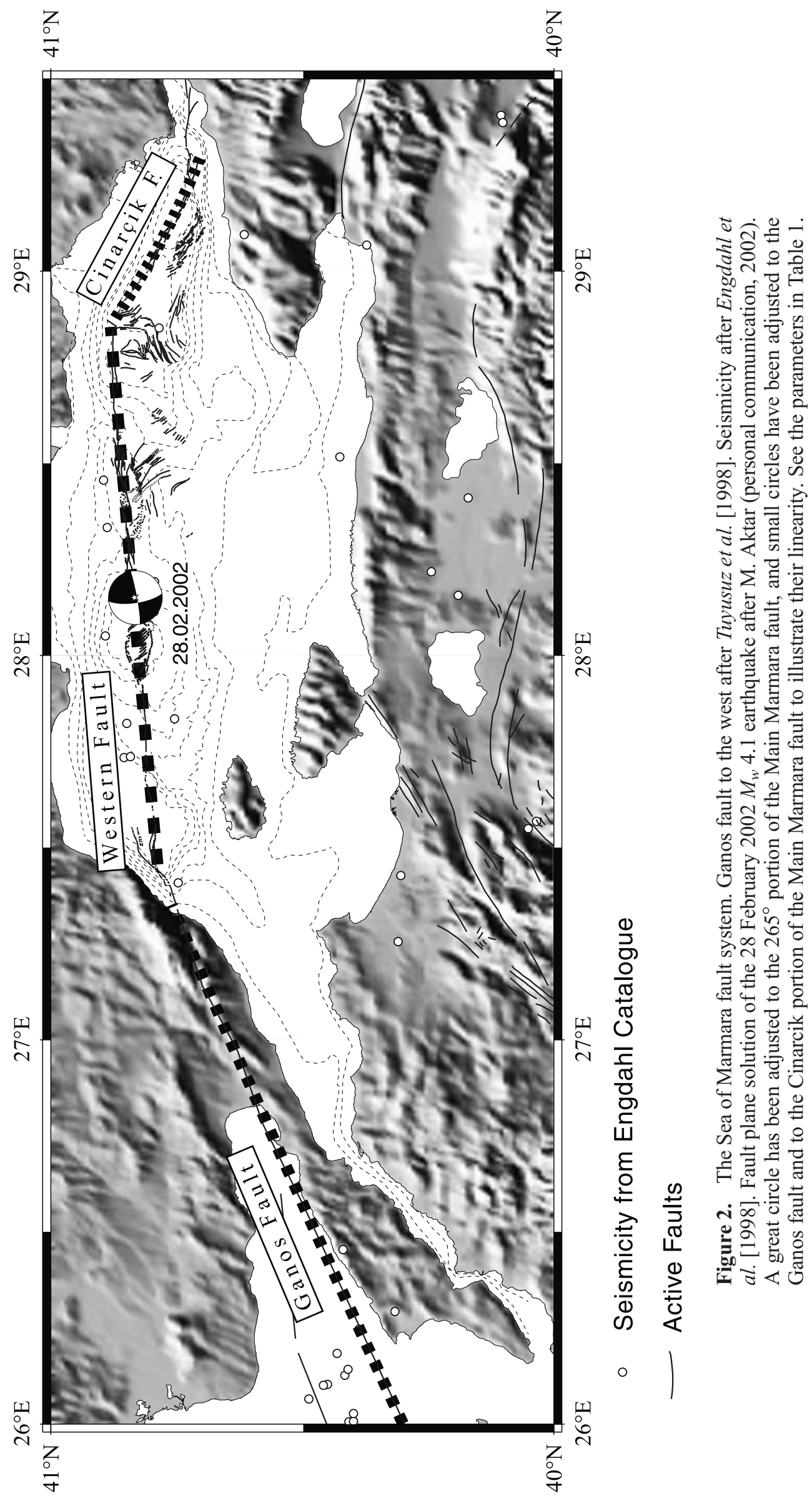


Table 1. Parameters of Small Circles Adjusted to Portions of Fault

\begin{tabular}{llllc}
\hline \multicolumn{1}{c}{ Fault Unit } & Latitude & Longitude & Radius, deg & Length, km \\
\hline Marmara northern branch & $36.1^{\circ} \mathrm{N}$ & $28.68^{\circ} \mathrm{E}$ & 4.77 & 420 \\
Western Main Marmara & $48.9^{\circ} \mathrm{S}$ & $35.8^{\circ} \mathrm{E}$ & 90 & 114 \\
Ganos & $15.9^{\circ} \mathrm{S}$ & $48.25^{\circ} \mathrm{E}$ & 59.89 & 142 \\
Cinarcik & $42.4^{\circ} \mathrm{N}$ & $30.25^{\circ} \mathrm{E}$ & 1.84 & 36 \\
1939 earthquake & $33.0^{\circ} \mathrm{N}$ & $35.09^{\circ} \mathrm{E}$ & 7.61 & 340 \\
1943 earthquake & $37.64^{\circ} \mathrm{N}$ & $34.61^{\circ} \mathrm{E}$ & 3.48 & 270 \\
1944 earthquake & $1.7^{\circ} \mathrm{S}$ & $40.13^{\circ} \mathrm{E}$ & 43.12 & 160 \\
\hline
\end{tabular}

$265^{\circ}$, whereas the eastern one fourth (the Cinarcik segment) is oriented $299^{\circ}$. The Cinarcik unit connects with the Gulf of Izmit segment of the North Anatolian fault that is oriented $270^{\circ}$. To test the linearities of the different portions of faults, we have adjusted small circles to the Ganos fault and to the two segments of the Main Marmara fault (Figure 2 and Table 1). Points were digitized every $4 \mathrm{~km}$ except within the complex Central Basin located in Figure 1 (see the discussion of this area below). The standard deviations of the small circles with respect to the actual traces of the fault, as mapped in Figures 1 and 2, are $<1 \mathrm{~km}$. The circle fitting the western segment is a great circle. This $115 \mathrm{~km}$ long fault is thus remarkably rectilinear. Note that the western Main Marmara fault shows no lateral step of the fault on either side of the Central Basin in either direction (compare Figures 1 and 2). Armijo et al. [2002] and Barka and Kadinsky-Cade [1988] have proposed that the Central Basin is an active pull-apart basin. The absence of a step was one of the arguments used by Le Pichon et al. [2001] to propose that the fault is continuous at depth and that the spindleshaped structure superficially resembling a pull-apart basin is not an active pull-apart but rather corresponds to a negative flower rotating clockwise. This is an important point as, if the Central Basin is an active pull-apart, a segmentation of the fault would be expected there, whereas if Le Pichon et al. [2001] are correct, this would not be the case. Recently, Demirbag et al. [2003] have shown that deep-towed seismic reflection data there are not compatible with a pull-apart structure.

[4] In Figure 2 we have added the location and focal mechanism of the recent 28 February $2002 M_{w} 4.1$ earthquake. The solution plotted is the one obtained by $\mathrm{M}$. Aktar and G. Orcalu (personal communication, 2002). The focal depth is given as $10 \mathrm{~km}$. The accuracy quoted by $\mathrm{M}$. Aktar is $1 \mathrm{~km}$ for the location of the epicenter and $5^{\circ}$ for the strike of the fault plane solution. This earthquake falls exactly on the Main Marmara fault as defined by Le Pichon et al. [2001], and its strike also agrees with the one they predict $\left(80 \pm 5^{\circ}\right.$ instead of $\left.85^{\circ}\right)$. Later we will demonstrate that this direction of motion is the one predicted by the geodesy.

[5] The circle fitting the $140 \mathrm{~km}$ long Ganos fault has a slight curvature toward the southeast. On the other hand, the circle fitting the Cinarcik unit has a very small radius and is strongly concave toward the northeast. As a result, if the motion along it is dextral strike slip, as proposed by $L e$ Pichon et al. [2001], the slip along it must impose on the Cinarcik basin floor a significant clockwise rotational component. We will come back to this later.

[6] Figure 2 demonstrates that at this scale the northern branch of the North Anatolian fault in the Sea of Marmara
[Sengör, 1979] consists of three remarkably linear portions of fault, with angular joins. The western Main Marmara fault segment makes an angle of $18^{\circ}$ with the Ganos fault. The Cinarcik unit makes an angle of $34^{\circ}$ with the western segment and of $30^{\circ}$ with the Izmit segment. The magnitude 5 or more earthquakes relocated by Engdahl et al. [1998], shown in Figure 2, occurred within $5 \mathrm{~km}$ of the western segment of the Main Marmara fault, a distance comparable to the probable accuracy of the localization. Thus this segment is presently seismically active, as confirmed by the February 2002 earthquake. This is corroborated by the distribution of the microseismicity [Gurbuz et al., 2000] (as will be shown in Figures 6 and 9). On the other hand, the part of the Ganos fault that was broken during the 19127.4 Sarkoy-Murefte earthquake [Ambraseys and Jackson, 2000] is presently aseismic for intermediate size earthquakes (Figure 1) as well as for microseismicity [Gurbuz et al., 2000].

\section{Topographic Offsets Along the Main Marmara Fault}

[7] Le Pichon et al. [2001] argued that the present course of the North Anatolian fault in the Sea of Marmara originated some 200,000 years ago by cutting across the older basin fabric generated by a dominant NNE-SSW extension. This was based on two main arguments. First, the fault has not yet reached its stable "residual structure," as defined by Tchalenko [1970]. Second, there is a $4 \pm 1 \mathrm{~km}$ dextral offset of the western margin of the Central Basin along the fault. The minimum age of the fault necessary to explain the offset, if the fault rate has been $\sim 20 \mathrm{~mm} / \mathrm{yr}$ since the initiation of the fault, is indeed 200,000 years.

[8] Figure 3 illustrates the $4 \pm 1 \mathrm{~km}$ dextral offset of northern portion of the Central Basin with respect to its southern portion. The existence of this offset had already been noted by Halbach et al. [2000] on the basis of a R/V Meteor bathymetric survey of the Western High. It was confirmed by the more complete mapping during the R/V Suroit cruise [Le Pichon et al., 2001]. The trace of the great circle that fits the western Main Marmara fault unit is shown in Figure 2 (see parameters in Table 1). This trace divides the basin into two dextrally offset portions (Figure 3a). A $4 \pm 1 \mathrm{~km}$ offset restores the symmetry of this basin (Figure 3b).

[9] Armijo et al. [2002] noted that a N-S fold north of the Central High, $50 \mathrm{~km}$ farther east, is dextrally offset along the trace of the Main Marmara fault. Figure 4 illustrates that this offset is also of about $4 \pm 1 \mathrm{~km}(3.5 \mathrm{~km}$ according to Armijo et al. [2002]). Finally, still $50 \mathrm{~km}$ farther east, at the eastern extremity of the Cinarcik Basin, the E-W Izmit fault cuts steeply across the margin that is dextrally offset by also about $4 \pm 1 \mathrm{~km}$ (Figures 1 and 5).

[10] The fact that the same $4 \pm 1 \mathrm{~km}$ offset is found over a $100 \mathrm{~km}$ distance, from the Izmit fault westward to a major portion of the Main Marmara fault, indicates that the motion of the Izmit fault is integrally transferred to the Main Marmara fault over its whole length. In other words, subsidiary faults do not carry a significant part of the motion that enters the Sea of Marmara with the Izmit fault. This fact also suggests that the first establishment of the Main Marmara fault along its present rectilinear trace occurred 

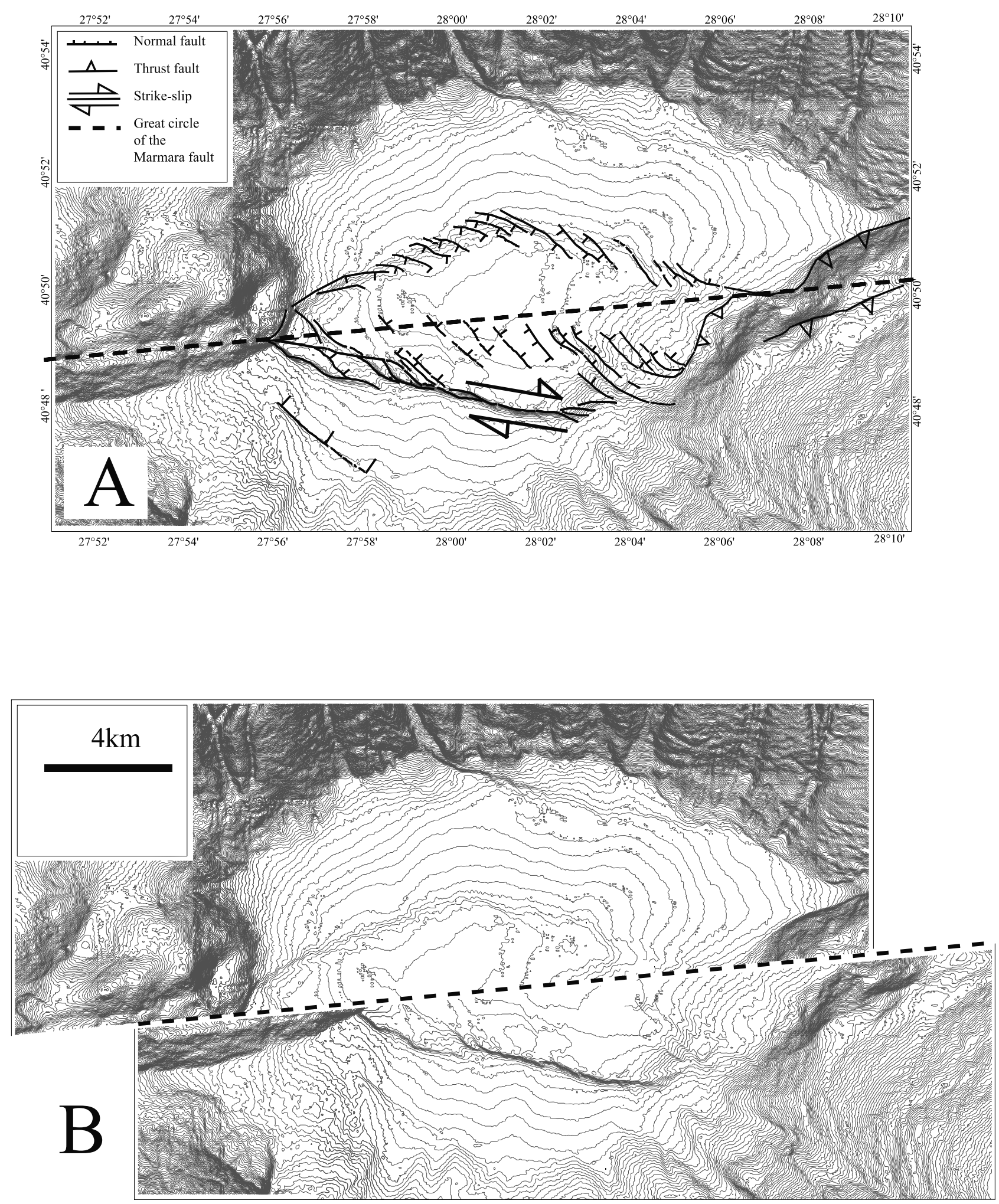

Figure 3. (a) Topographic map of the Central Basin. See location in Figure 1. The trace of the great circle fitting the Main Marmara fault divides the basin in two dextrally offset portions. (b) Reconstructed basin after the $4 \mathrm{~km}$ offset is removed. 

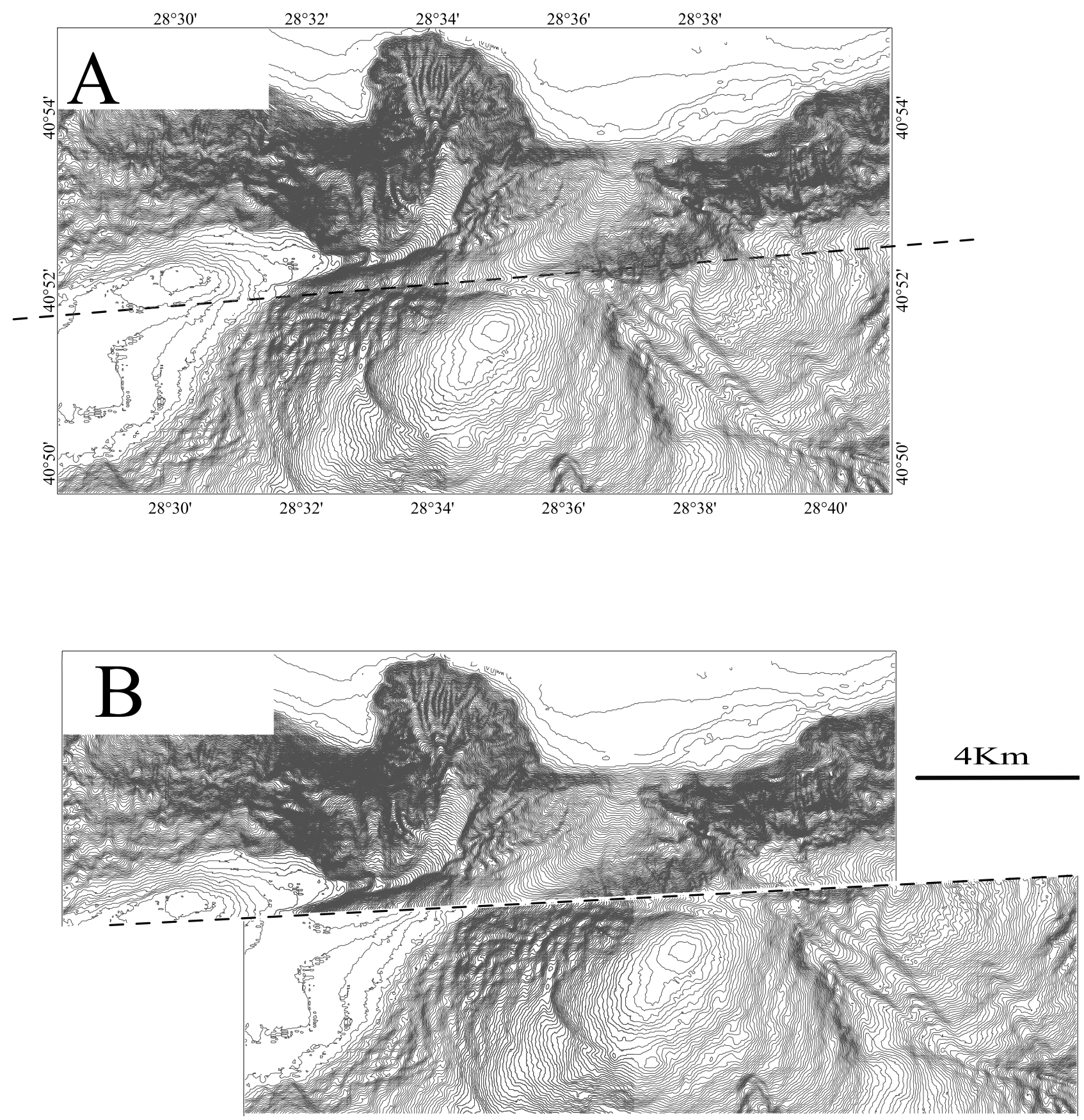

Figure 4. (a) Topographic map of the passage of the Main Marmara fault across two offset portions of a $\mathrm{N}-\mathrm{S}$ fold north of the Central High, at the base of the northern continental margin. See location in Figure 1. (b) Reconstructed fold after the $4 \mathrm{~km}$ offset has been removed.

about 200,000 years ago when the $4 \pm 1 \mathrm{~km}$ offset began to be created.

\section{GPS and Kinematics}

[11] The northern branch of the North Anatolian fault [Sengör, 1979] follows the Main Marmara fault within the Sea of Marmara and then the Ganos fault [Le Pichon et al., 2001]. The motion along this northwestward extension is different from the motion along the main part of the North Anatolian fault [Straub and Kahle, 1994; Straub, 1996].
The Anatolian block rotates about an Euler pole near the Nile delta with respect to Europe [Le Pichon et al., 1995, 1994; McClusky et al., 2000; Reilinger et al., 1997]. The Euler vector was last determined on the basis of GPS measurements by McClusky et al. [2000] (see Table 2) and the North Anatolian fault follows approximately a small circle about this pole of rotation. The Marmara region, limited to the north by the Ganos-Main Marmara fault system, is situated well to the north of the westward extension of this small circle (Figure 6). If the motion within the Marmara region were the Anatolia/Eurasia 

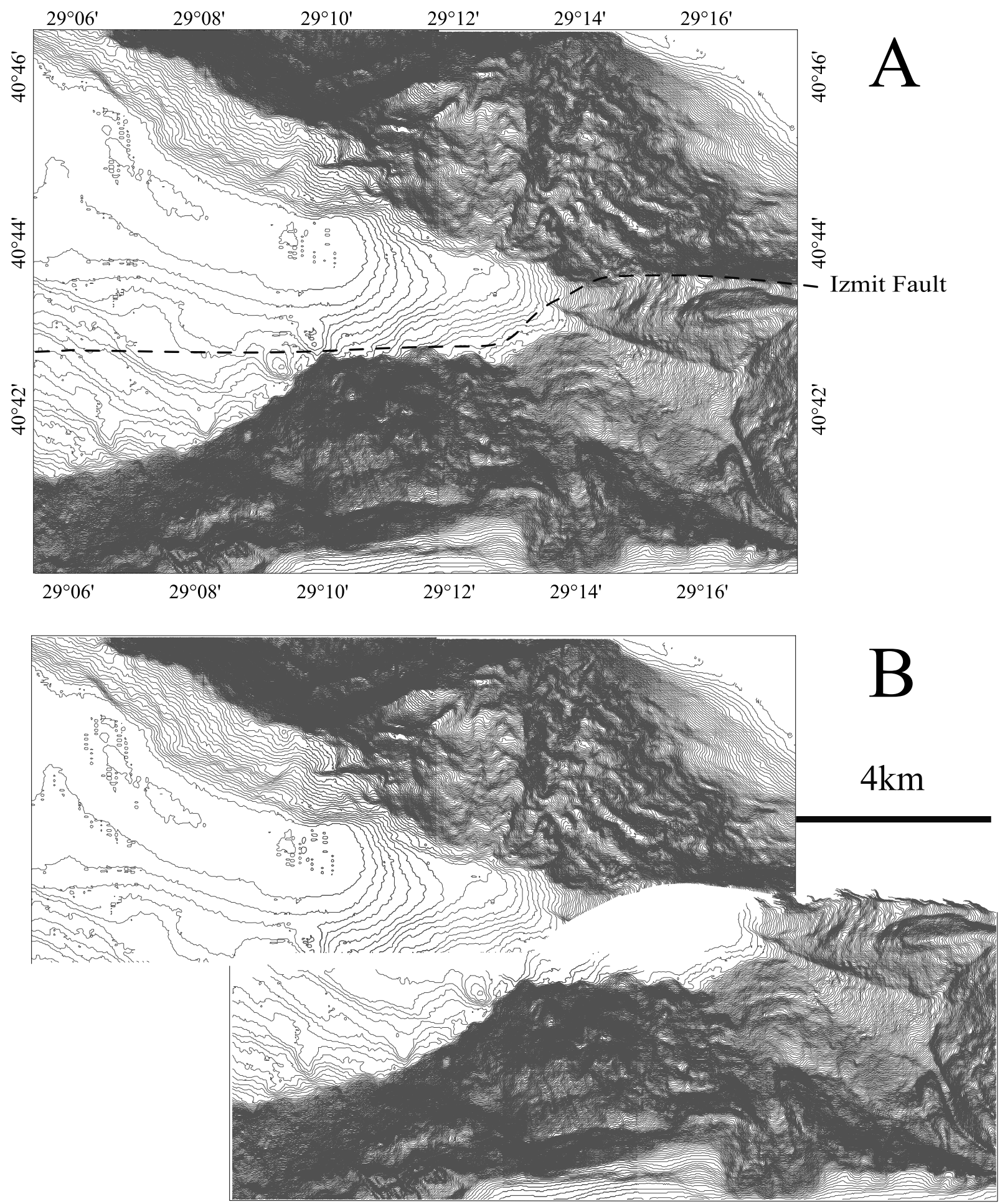

Figure 5. (a) Topographic map of eastern extremity of Cinarcik basin. See location in Figure 1. The Izmit fault follows a $4 \mathrm{~km}$ dextral offset of the southern margin. (b) Reconstructed margin after the $4 \mathrm{~km}$ offset has been removed.

motion, one would expect a significant component of extension along its northern boundary in agreement with the interpretation of the Sea of Marmara as a pull-apart [Armijo et al., 1999]. However, as shown in Figure 6, the GPS vectors in the Sea of Marmara region have a strong curvature that differs from the curvature of the dashed black small circle that coincides with the North Anatolian fault.
They actually make an angle of $20^{\circ}$ with the Eurasia/ Anatolia small circle in Figure 6.

[12] What is then the type of faulting along the Main Marmara fault? Le Pichon et al. [1999] noted that the GPS sites, as given by Straub and Kahle [1994] and Straub [1996], do not reveal significant internal deformation within a band $60-70 \mathrm{~km}$ wide, south of the Ganos-Main Marmara 
Table 2. Kinematic Parameters

\begin{tabular}{|c|c|c|c|c|}
\hline Pole & Latitude & Longitude & $\begin{array}{c}\text { Rotation Rate, } \\
\text { deg/Myr }\end{array}$ & Reference \\
\hline $\mathrm{Ana} / \mathrm{Eu}$ & $30.7^{\circ} \mathrm{N}$ & $32.6^{\circ} \mathrm{E}$ & 1.2 & McClusky et al. [2000] \\
\hline $\mathrm{Ana} / \mathrm{Eu}$ & $32.37^{\circ} \mathrm{N}$ & $31.72^{\circ} \mathrm{E}$ & 1.59 & Meade et al. $[2002]^{\mathrm{a}}$ \\
\hline $\mathrm{Mar} / \mathrm{Eu}$ & $37.78^{\circ} \mathrm{N}$ & $28.29^{\circ} \mathrm{E}$ & 3.13 & Le Pichon et al. [1999] \\
\hline $\mathrm{Mar} / \mathrm{Eu}$ & $36.9^{\circ} \mathrm{N}$ & $28.6^{\circ} \mathrm{E}$ & 3.24 & Meade et al. $[2002]^{\mathrm{a}}$ \\
\hline $\mathrm{Mar} / \mathrm{Eu}$ & $36.1^{\circ} \mathrm{N}$ & $28.68^{\circ} \mathrm{E}$ & 2.50 & this paper \\
\hline Mar/Anatolia & $41.14^{\circ} \mathrm{N}$ & $25.21^{\circ} \mathrm{E}$ & 1.67 & Meade et al. [2002] $]^{\mathrm{a}}$ \\
\hline Cinarcik/Eu & $42.4^{\circ} \mathrm{N}$ & $30.25^{\circ} \mathrm{E}$ & -6.44 & this paper \\
\hline Cinarcik/Mar & $40.63^{\circ} \mathrm{N}$ & $29.78^{\circ} \mathrm{E}$ & -8.89 & this paper \\
\hline
\end{tabular}

${ }^{\mathrm{a}}$ Derived from the vectors of motion on the boundaries of the Marmara block.

fault system. They consequently proposed to define a Marmara block between the northern and southern branches of the North Anatolian fault (for these branches, see Sengör [1979] and Sengör et al. [1985]). The GPS sites within the Marmara block then could be used to determine its relative motion with respect to Eurasia as well as the elastic effects produced by locking on the fault. A local reference frame north of Marmara was obtained by setting the velocity of Istanbul to 0 as by Straub and Kahle [1994] and Straub [1996]. They concluded that the relative motion along the Main Marmara and Ganos faults, as given by GPS, was pure dextral strike-slip and that its magnitude was $18 \mathrm{~mm} / \mathrm{yr}$. The Euler vector they used is given in Table 2, and Figure 6 shows in dashed orange the small circle about this pole that describes the geometry of the Ganos and Main Marmara faults.

[13] Recently, an updated version of the GPS velocity field published by McClusky et al. [2000], which includes data collected through 1999 before the Kocaeli earthquake, was used by Meade et al. [2002] to make block models of secular deformation in the Marmara area. With respect to McClusky et al. [2000], this updated data set contains new critical sites close to the Main Marmara fault that include site MISL on Marmara island and sites MAER and SELP on the north shore of the Sea of Marmara (see locations in Figure 6). In the following we use this data set.

[14] Meade et al. [2002] define a Marmara block similar to the one proposed by Le Pichon et al. [1999], between the northern branch of the North Anatolian fault, formed by the Izmit-Main Marmara-Ganos system, and a simplified southern branch that separates this block from Anatolia. For the Main Marmara fault, they test two possible positions: one along the northern margin of the Sea of Marmara and the other (that they adopt) joining directly the Ganos unit to the Izmit unit, along the southern margin. The Main Marmara fault, as mapped by Le Pichon et al. [2001] follows the northern margin, in its eastern portion, and joins obliquely the southern margin to the northern margin in its western portion. It is thus closer to the first position than to the second one. Meade et al. [2002] solve for the relative motions of the Eurasia, Marmara, and Anatolia blocks assuming that the faults are dislocations in an elastic halfspace with variable locking depth. We refer to their discussion for the justification of the choice of this type of model. They demonstrate that a solution can be obtained in which the residuals are everywhere within the uncertainties. Their solution is obtained on a plane and consequently the parameters of their Euler vectors are not exactly the equiv- alent of those obtained for a spherical earth. In addition, they do not give the parameters of rotation of the Marmara block with respect to Eurasia and Anatolia. However, in order to compare their solution with ours, we computed the spherical Euler vectors compatible with the velocity vectors they show along the northern and southern boundaries of the Marmara block (see Table 2). Their Marmara/Eurasia pole of rotation is situated $0.9^{\circ}$ to the south of the Le Pichon et al. [1999] pole. It results in pure dextral strike-slip along the western long segment of the Main Marmara fault (violet small circle in Figure 6). The strike-slip velocity at $25 \mathrm{~mm} /$ yr is significantly larger than the $18 \mathrm{~mm} / \mathrm{yr}$ obtained with the Straub [1996] data. The Anatolia/Eurasia Euler vector obtained by summation of the Marmara/Eurasia and Marmara/Anatolia vectors derived from their figure is reasonably close to the one given by McClusky et al. [2000] (see Table 2). It gives North Anatolian fault velocities that are $2 \mathrm{~mm} / \mathrm{yr}(9 \%)$ faster.

[15] Meade et al. [2002] do not use the Eurasian frame but define a local reference frame north of the North Anatolian fault. However, the residuals in the European velocity frames as given in their paper are small and comparable to the ones they obtain in the local frame (less than 2-3 mm/yr, see Figure 6). We thus use the European velocity frame and consider that it is not significantly different from the local frame used by Meade et al. [2002]. We have used eleven GPS sites located within 60 $\mathrm{km}$ of the fault, between $26^{\circ} \mathrm{E}$ and $29^{\circ} 09^{\prime} \mathrm{E}$, to determine the position of the Marmara/Eurasia pole of rotation in the area where the southern branch is situated more than $60 \mathrm{~km}$ from the northern one. Because there are significant elastic effects, as demonstrated by Meade et al. [2002], we only invert the azimuths. As the elastic effects are essentially parallel with the vectors, they do not significantly affect the azimuths. Eight of the 11 azimuths are adjusted to better than $1^{\circ}$, and the overall standard deviation is $2^{\circ}$. Because of the strong curvature (the azimuth varies from $242^{\circ}$ to $275^{\circ}$ ), the inversion is robust. The Euler pole obtained (see Table 1) is situated $0.8^{\circ}$ farther south than the one derived from Meade et al. [2002] but gives kinematic results that are very similar along the Ganos-Marmara fault system (blue small circle in Figure 6). We have checked, however, that using the position of the pole derived from Meade et al. [2002] leads to a significant deterioration of the fit to the azimuths, probably because of the planar assumption they make. Figure 6 demonstrates that with the Marmara rotation determined, the geometry of the northern branch of the North Anatolian fault can be described well by a single small circle. In other words, to a good approximation, the relative motion along the entire system is indeed pure dextral strike slip. Figure 6 also shows how the relatively straight different fault units closely follow this small circle. More precisely, with the Euler pole that we obtained, the western portion of the Ganos fault closely follows the small circle with a radius of $4.70^{\circ}$ and the western segment of the Marmara fault follows closely a slightly larger small circle that has a radius $4.77^{\circ}$. Both portions of fault thus are pure strike slip. The eastern portion of the Ganos fault in between has a slight shortening component of $<4 \mathrm{~mm} / \mathrm{yr}$, and the Izmit portion also has a small shortening component.

[16] Meade et al. [2002] find an average locking depth of $17 \mathrm{~km}$ on the faults limiting the Marmara block, both 


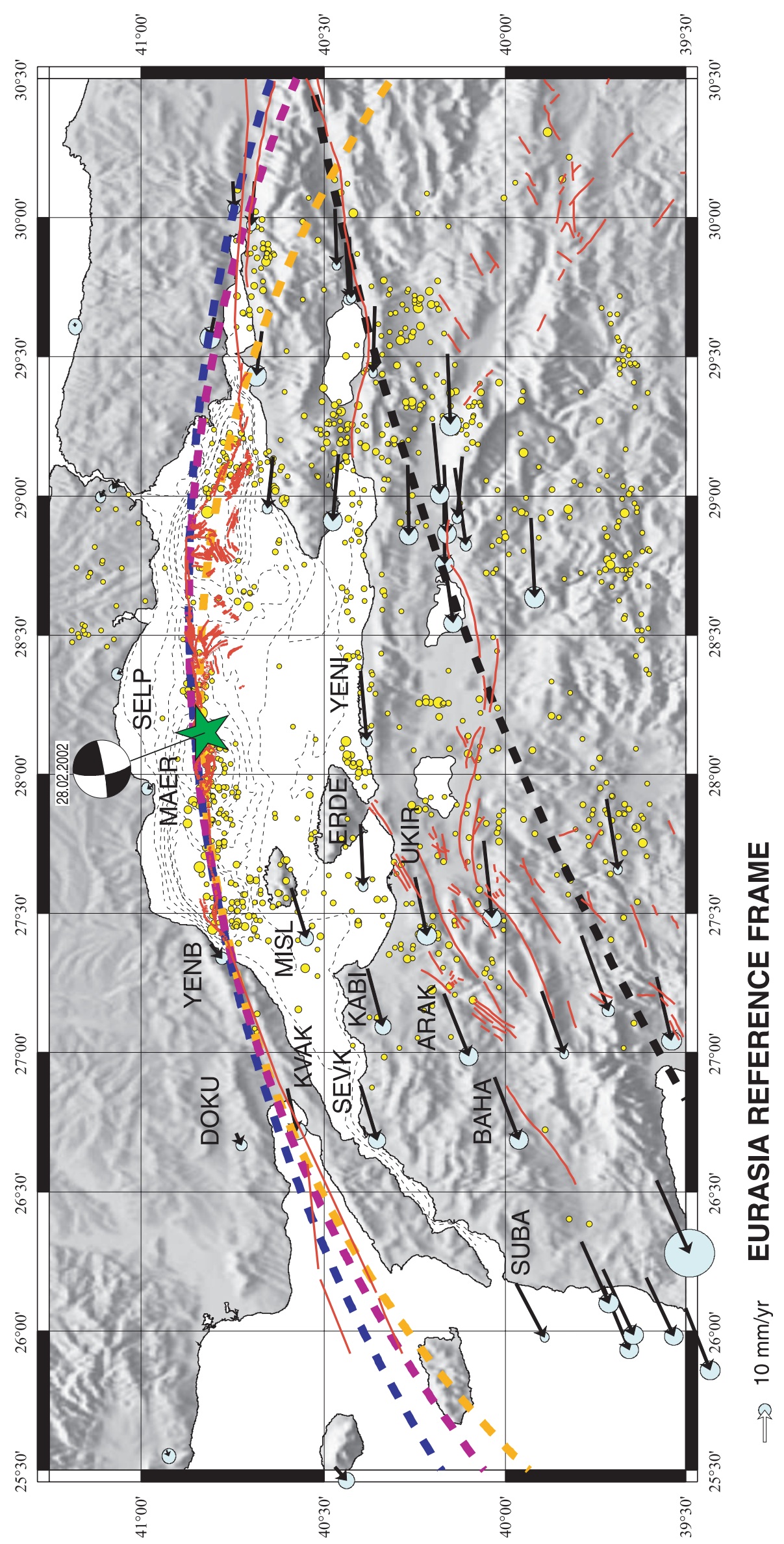

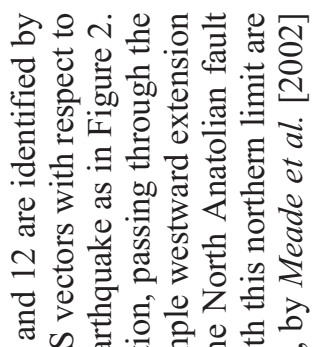

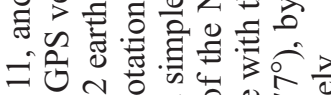

요유.

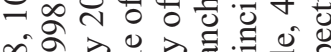

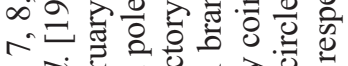

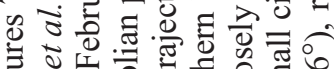

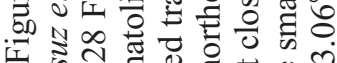

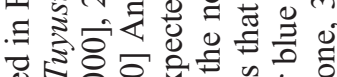

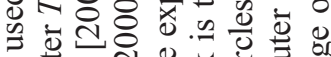

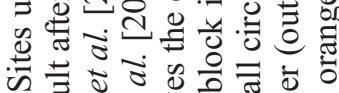

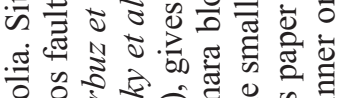

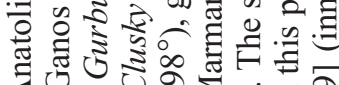

《ن

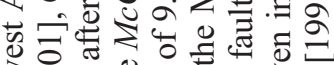

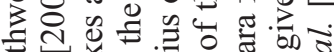

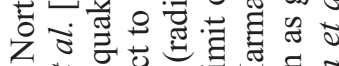

Ð む)

कू छ

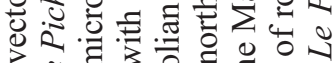

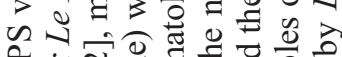

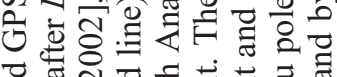

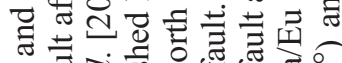

छิ

फั

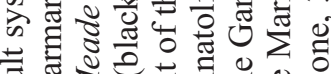

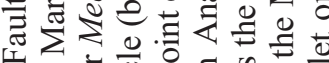

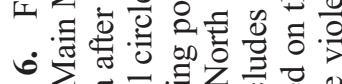

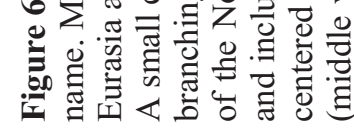


to the north and south, except on the Sea of Marmara fault where they identify problems that will be discussed later. They demonstrate the existence of elastic loading at the full relative block velocity. This elastic loading consequently cannot be ignored. We adopt a simpler approach to identify and visualize separately the elastic effects related to the Ganos and Main Marmara faults. We confine our analysis to the area west of $29^{\circ} \mathrm{E}$ because east of it the two branches become so close that their elastic effects strongly overlap. This eastern limit enables us not to deal with the complexity of the Cinarcik basin. We also avoid the complexity related to the tectonics to the south of the Marmara block by eliminating sites situated close to or south of the southern fault system.

[17] We first examine the Ganos fault, where the position of the fault is not disputed [Sengör, 1979; Sengör et al., 1985; Tuyusuz et al., 1998; Armijo et al., 1999; Okay et al., 1999], to recover the Marmara rotation velocity. We then consider the more complex case of the Main Marmara fault. We impose the position of the Marmara Euler pole determined above and want to recover the rotation velocity. We adopt the model proposed by Savage and Burford [1973] for the elastic two-dimensional strike-slip case. The analytical formulation that they give is based on a dislocation model with no slip on the fault above depth $\mathrm{z}$ and slip by a constant amount below this surface. It can be derived using a screw dislocation [Weertman and Weertman, 1964]. The same analytical solution had earlier been used by Chinnery [1961] as the limiting case of a rectangular dislocation growing to infinity. This analytical very simple model has the great advantage to allow a systematic examination of the elastic effects along the fault in a homogeneous way.

[18] The assumption of pure strike-slip is justified because the trace of the $420 \mathrm{~km}$ long North Anatolian northern branch lies close to a small circle with respect to the Euler pole (see Figure 6). However, is the adoption of two-dimensionality justified? This would certainly not be the case if we were considering coseismic dislocations of $100-150 \mathrm{~km}$ length. In that case [see, e.g., Chinnery, 1961], the two ends of the dislocation significantly modify the two-dimensional (2-D) solution in the zone we are interested in. However, as we are dealing with interseismic elastic deformation and as at the present time, all segments of this branch appear to be locked, there is no important discontinuity in the elastic deformation at the extremities of each segment of fault. $70 \%$ of the elastic deformation occur within a distance $2 z(20-30 \mathrm{~km})$ of the fault and $85 \%$ within a distance of $5 z$. It is mostly the data within $2 z$ of the fault that determine the inversion, and this distance is small with respect to the $420 \mathrm{~km}$ length of the fault. Thus the 2-D approximation is reasonable. In any case, as pointed out by Savage [1990, p. 4878], “even high quality measurements across a transform fault are incapable of defining the deformation mechanism at depth." Our aim is not to define precisely this mechanism but rather to identify the variations in elastic deformation along the different segments of the northern branch of the North Anatolian fault. Even if our model has small systematic errors, the comparison between segments along the fault will still be significant, as the systematic errors will be quite similar.

[19] With this 2-D model, we make a norm L1 simultaneous inversion for the location of the fault, the depth of locking on the fault, and the fault slip velocity with the corresponding Marmara rotation velocity. We use an L1 norm to avoid excessive influence of deviant measurements, but we have checked that using an L2 norm does not significantly change the results. We project the GPS velocities on the small circles defining the motion. This fault parallel velocity is the strike-slip component of the GPS velocities that is then compared to the modeled pure strikeslip velocity. We minimize the sum of the deviations between modeled velocities and measured ones. The misfit criterion in Figure 7 is the average deviation in $\mathrm{mm} / \mathrm{yr}$. We use eight sites situated between $26^{\circ} 30^{\prime} \mathrm{E}$ and $27^{\circ} 21^{\prime} \mathrm{E}$, identified both on Figure 7 and located on Figure 8. We eliminate sites situated more than $60 \mathrm{~km}$ south of the fault (where the expected elastic effect would be $<1.5 \mathrm{~mm} / \mathrm{yr}$ and where the influence of the southern branch begins to be felt). For site KVAK situated very close to the fault and the position of which is known with respect to the fault, we impose the actual distance to the fault. The inversion recovers the actual position of the fault, at a distance of $4.7^{\circ}$ from the pole (small circle in Figure 9) and gives a velocity on the fault of $22.8 \mathrm{~mm} / \mathrm{yr}$ (corresponding to an angular velocity of $2.5^{\circ} \mathrm{Myr}$ ) and a locking depth of $13 \pm 2$ $\mathrm{km}$. The average misfit of the velocities is $0.18 \mathrm{~mm} / \mathrm{yr}$ (Figure 7). We tested that eliminating site KVAK did not change the result of the inversion.

[20] There is a trade-off between velocity and locking depth. If we impose the locking depth of $17 \mathrm{~km}$ obtained by Meade et al. [2002], the velocity becomes $23.7 \mathrm{~mm} / \mathrm{yr}$, but the misfit criterion shows a significant increase from 0.18 to $0.27 \mathrm{~mm} / \mathrm{yr}$. The velocity obtained is still about $5 \%$ smaller than the one obtained by Meade et al. [2002], but the error bars of the two velocities overlap. We adopt the $2.5^{\circ} \mathrm{Myr}$ rotation velocity. We then impose this solution on all sites between $26^{\circ} \mathrm{E}$ and $29.7^{\circ} \mathrm{E}$ to test whether it gives a reasonable fit to data. We choose a locking depth of $14 \mathrm{~km}$ in the upper range of our solution to be as close as possible to the $17 \mathrm{~km}$ of the solution obtained by Meade et al. [2002] and still give a good fit to the data. We also choose a position of the fault along the small circle with a radius of $4.70^{\circ}$ that fits the Ganos fault as in Figure 7. Figures 8 and 9 show that the fit is fairly good, except for sites situated more than about $60 \mathrm{~km}$ from the fault that are close to or south of the southern fault branch. Our solution gives a slightly slower velocity than the one of Meade et al. [2002] (23 instead of $25 \mathrm{~mm} / \mathrm{yr}$ ), but the differences between the two solutions are within the uncertainties ( $\pm 2 \mathrm{~mm} / \mathrm{yr}$ for the Meade solution). We take this overall agreement between the results of our two different solutions as an a posteriori justification of our simple 2-D approach.

[21] Figures 8 and 9 show that the residuals, within $60 \mathrm{~km}$ to the south of the Ganos-Marmara fault, are $<0.7 \mathrm{~mm} / \mathrm{yr}$ as an average after the correction of the elastic effect. This is a corroboration of the demonstration made by Meade et al. [2002] that the Marmara block behaves as a rigid entity. Beyond $60 \mathrm{~km}$ to the south of the fault, the velocities increase indicating that this area does not belong to the Marmara block but has a relative southwestward velocity and/or begins to feel the elastic effect of this increase in velocity. We have identified by full dots in Figure 8 the sites that are affected by the Marmara fault. The four sites 


\section{GANOS FAULT}

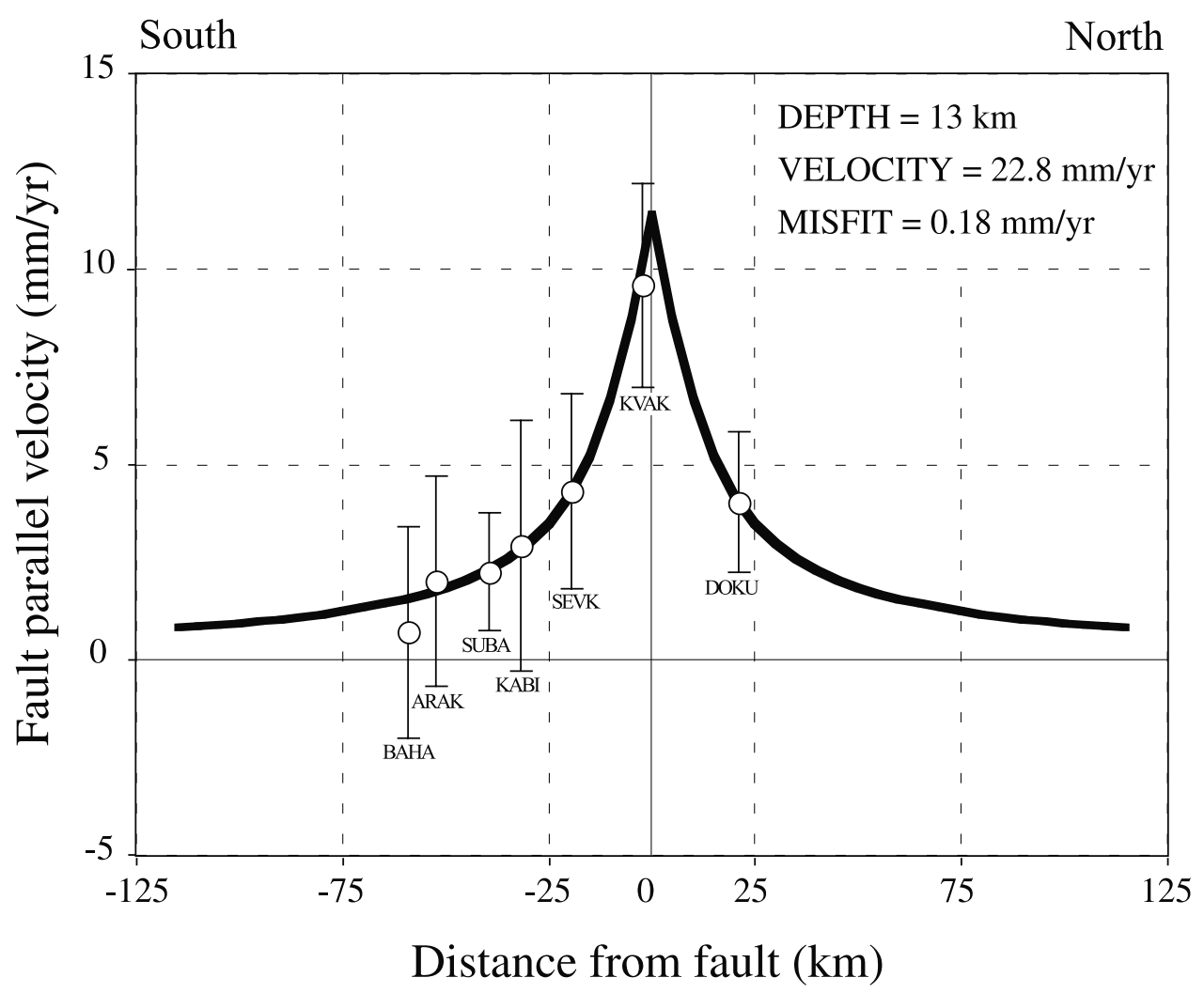

Figure 7. Simultaneous inversion of Ganos fault position, strike-slip velocity, and locking depth. The position of the Marmara pole of rotation is imposed at $36.1^{\circ} \mathrm{N}$ and $28.68^{\circ} \mathrm{E}$ (see text). The part of the GPS velocity (projected along the fault trend modeled by a small circle) that is due to the elastic effect versus distance from the fault is shown. The best model is found by inverting for the position of the fault (radius of $4.7^{\circ}$ ), the block velocity, and the depth of locking that give the best fit in an L1 norm inversion. Sites (identified by name) between $26.5^{\circ} \mathrm{E}$ and $27.35^{\circ} \mathrm{E}$ and within $60 \mathrm{~km}$ to the south of the fault are used for the inversion. See their locations in Figure 6.

(MAER, SELP, YALI, and DEMI) situated to the north of the fault appear to show no elastic effect. Yet sites MAER and SELP are situated only 15 and $21 \mathrm{~km}$, respectively, away from the fault ( 23 and $29 \mathrm{~km}$ in the solution of Figures 8 and 9 because the position chosen for the fault that fits the Ganos fault is $8 \mathrm{~km}$ south of the actual one in the Sea of Marmara). The elastic effect expected there are 5 and $4 \mathrm{~mm} / \mathrm{yr}$, respectively. This fact led Meade et al. [2002] to test separately the conditions of locking on the Marmara fault. They found that the locking depth that can fit the data is only $6.5 \pm 1.1 \mathrm{~km}$ when they put the fault along the southern margin of the basin and that the locking depth decreases to a negligible value when they put the fault along the northern margin. In other words, with the position of the fault situated close to (in the west) or along the northern margin (in the center and east) found by Le Pichon et al. [2001] (see Figure 1), the fault would be unlocked there.

\section{Depth of Locking on the Marmara Fault}

[22] We thus examine more carefully the eight sites directly related to the Marmara fault, between $27^{\circ} 24^{\prime} \mathrm{E}$ and $29^{\circ} \mathrm{E}$, excluding sites more than $60 \mathrm{~km}$ to the south of the fault (see Figures 9 and 10). In the inversion of
Figure 10, the position of the fault is found $12 \mathrm{~km}$ south of the actual fault (distance $4.66^{\circ}$ from the pole instead of $4.77^{\circ}$ ). This is because the inversion tries to fit sites MAER and SELP that show no significant elastic effect. The locking depth then is $\sim 10 \mathrm{~km}$ and the velocity $\sim 22 \mathrm{~mm} /$ yr. The fit is fair to the south but not to the north. If we impose on the other hand the actual position of the fault and the velocity of the block as determined in the inversion of the Ganos fault sites, the locking depth decreases to $2 \mathrm{~km}$ and the fit is fair to the north but very poor to the south (Figure 11).

[23] Figures 10 and 11 demonstrate that if the two velocities measured at the two sites MAER and SELP are correct, there is a strong N-S asymmetry with a well expressed elastic effect to the south but very little of it to the north. Meade et al. [2002] have carefully reviewed these two sites and the authors have no reason to suspect that the data there are erroneous (R. Reilinger, personal communication, 2001). If so, no variation in the locking depth will ever be able to fit both sides simultaneously. This is because the data indicate that the elastic deformation of the northern side is less than that of the southern one.

[24] Then what are the possible causes of this asymmetry? The first possibility is to assume that the fault has a 


\section{GANOS-MARMARA FAULT W $30^{\circ}$ E}

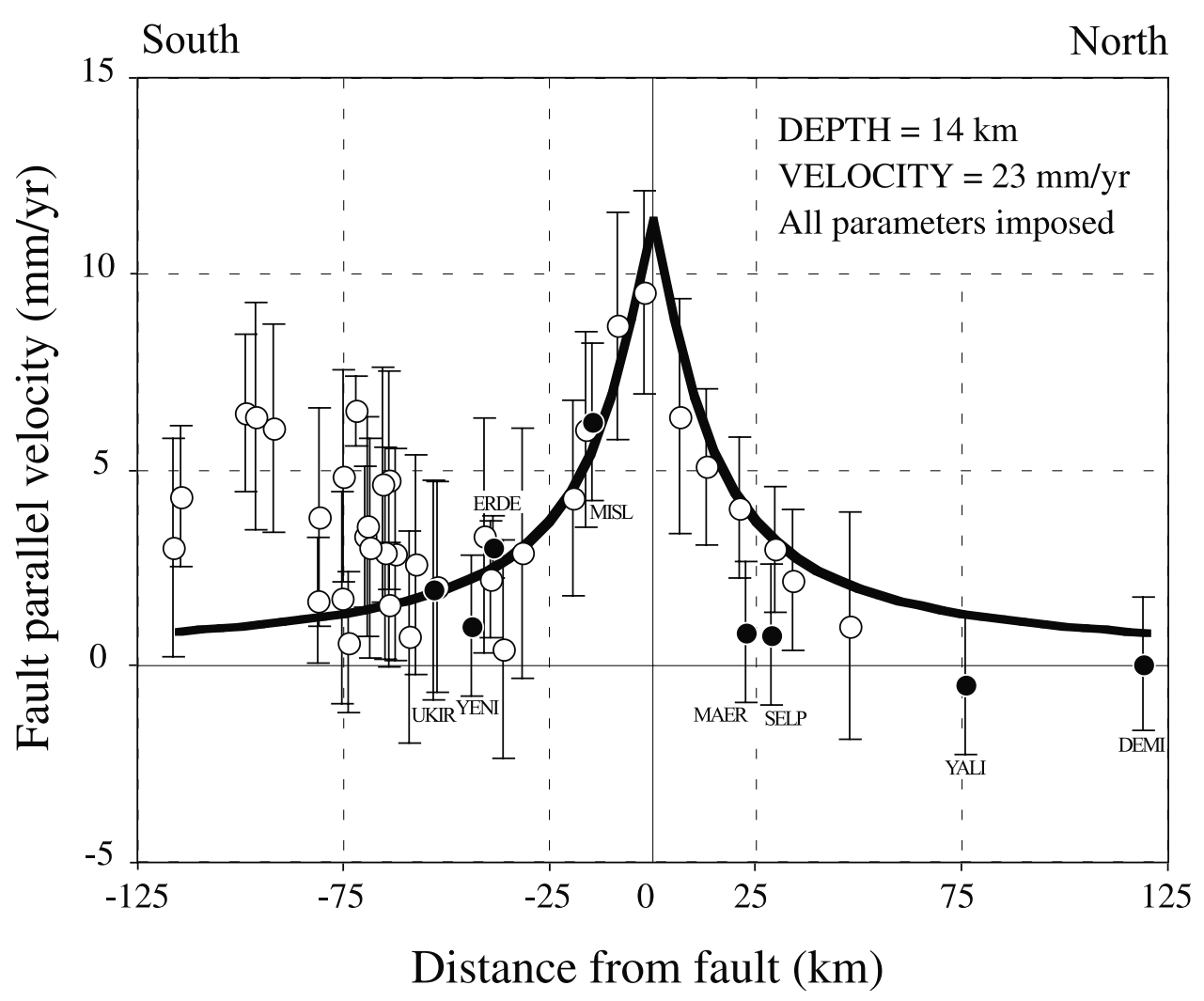

Figure 8. Plots of all sites between $26^{\circ} \mathrm{E}$ and $29.7^{\circ} \mathrm{E}$ with the solution of Figure 7. Note the increase in velocity to the south of the complex southern branch of the Anatolian fault. Sites identified by a black dot are the Marmara sites treated separately in Figures 10,11, and 12. Note that they show no elastic effect to the north of the fault. See their position in Figure 6.

shallow $\left(45^{\circ}\right)$ dip to the south. Because the fault is locked, the interseismic deformation only depends on the position of the base of the locked part of the fault, reflecting the motions of the underlying "ductile" middle and lower crust on each side of it. Then the base of the locked fault would be situated $\sim 12 \mathrm{~km}$ to the south of the surface trace and everything would happen as if the fault were located there. The solution would be the same as in Figure 10. It is acceptable although MAER and SELP are still poorly fit. However, this solution does not fit either the microearthquake distribution after Gurbuz et al. [2000] that is approximately symmetrical with respect to the fault nor the $10 \mathrm{~km}$ deep earthquake of February 1992 that occurred on a vertical fault plane (Figure 6).

[25] The second possibility is that the asymmetry in elastic deformation reflects an asymmetry in the elastic modulus $E$. The northern side would have to be more rigid than the southern one. If at the limit the northern side were infinitely rigid, all the elastic motion would be found on the southern one. The symmetry we had in the previous elastic solutions is due to the fact that we assumed implicitly that the elastic properties are the same on both sides. However, in the 2-D solution we use, with elastic properties that are different on both sides of the fault, the elastic deformation on each side is inversely proportional to the elastic modulus $E$.
[26] We now search for the best asymmetric distribution of elastic deformation that fits the data. We consequently fix the position of the fault at its actual position (distance of $4.77^{\circ}$ ). We also fix the Marmara block Euler vector previously obtained $\left(4.50^{\circ} / \mathrm{Myr}\right)$. We then invert for the locking depth and for different slip velocities on the north and south sides with the condition that the sum of both be equal to the total slip velocity of $23 \mathrm{~mm} / \mathrm{yr}$. Figure 12 shows the corresponding expected elastic effect (straigth line) as well as the predicted velocity with respect to the north (dashed line). The fit is good (average deviation of $0.42 \mathrm{~mm} / \mathrm{yr}$ ) with a reasonable locking depth of $10.5 \mathrm{~km}$. The southern slip velocity is now $21 \mathrm{~mm} / \mathrm{yr}$ whereas the northern one is 10 times smaller. This implies that the equivalent elastic modulus, acting over distances of $10 \mathrm{~km}$ or more, is 10 times larger to the north than to the south. The axis of symmetry of the total velocity curve in Figure 12 is displaced $10 \mathrm{~km}$ to the south of the fault. This explains why the inversion moves the position of the fault $\sim 10 \mathrm{~km}$ to the south of the actual one. The same asymmetry would apply to the coseismic motion during the earthquake rupture. We will come back later to the implications of this asymmetry on the seismic potential of the Marmara region.

[27] We have tested that this asymmetry is not found east of $29^{\circ} \mathrm{E}$, where the width of the basin becomes quite small and actually vanishes east of $29.5^{\circ} \mathrm{E}$. To the west, site 


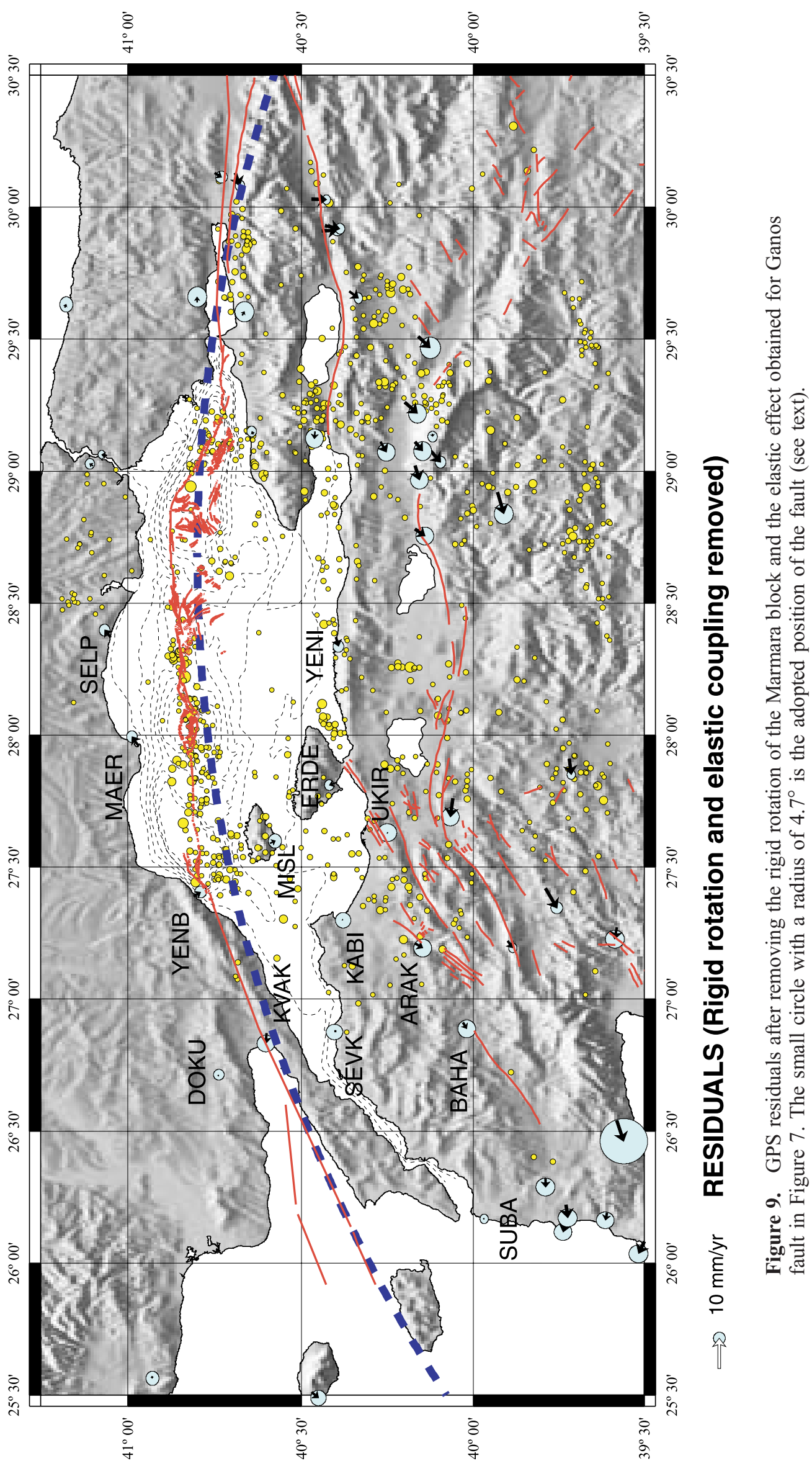




\section{MARMARA FAULT}

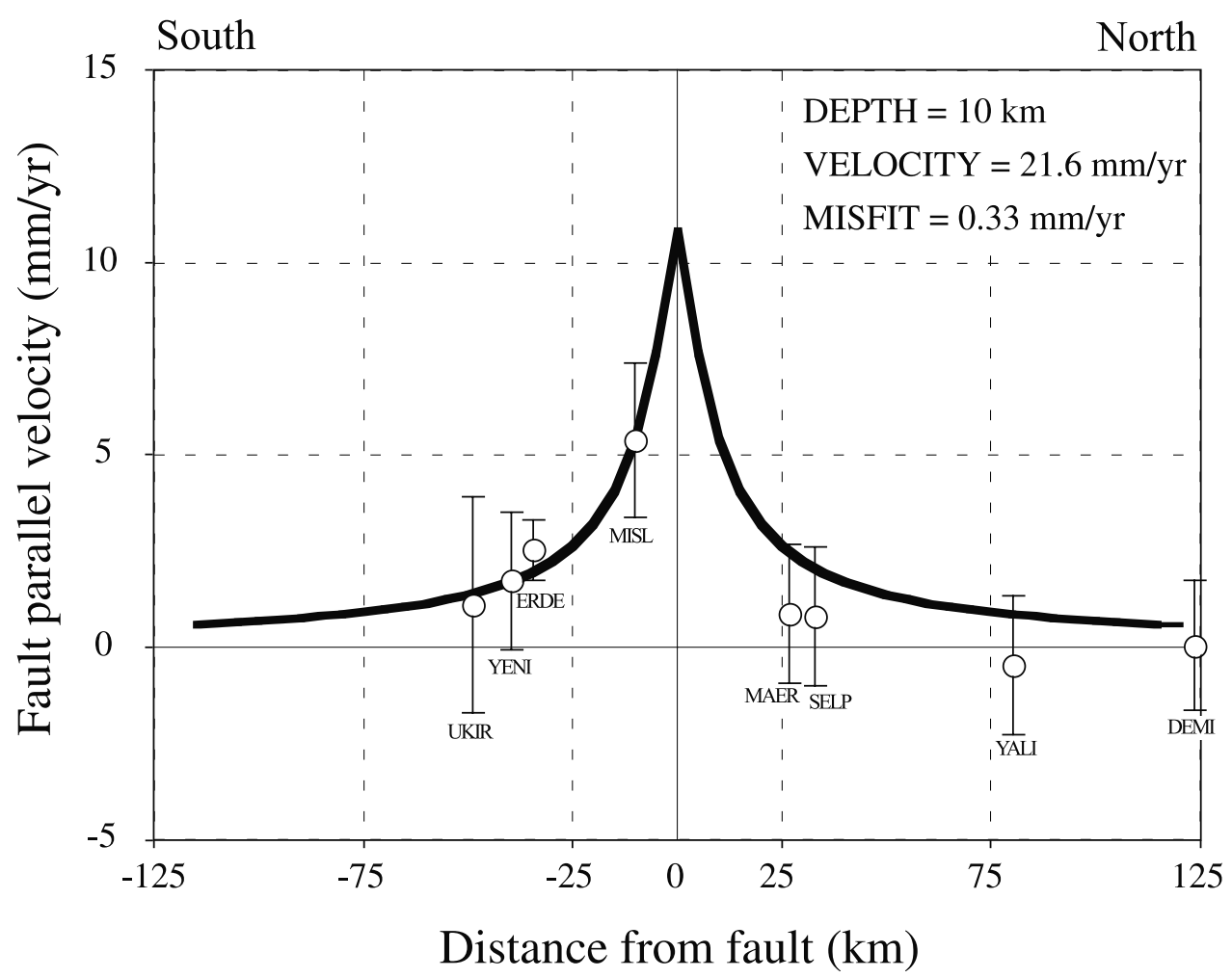

Figure 10. Same as Figure 7 for the Main Marmara fault. Sites between $27.4^{\circ} \mathrm{E}$ and $29^{\circ} \mathrm{E}$ and within 60 $\mathrm{km}$ to the south of the fault are used for the inversion. The inversion finds a "best" fault located $12 \mathrm{~km}$ to the south of the actual fault. It cannot fit the sites to the north. See locations of sites in Figures 6 and 9.

YENB (see location in Figure 6), $5 \mathrm{~km}$ to the north of the fault, on the western shore of the Sea of Marmara, is compatible with a velocity of $6 \mathrm{~mm} / \mathrm{yr}$ on the north side of the fault. The asymmetry there has already decreased by a factor of 3 . Thus the strong asymmetry is confined to the main part of the basin where the fault gets close to the northern margin.

\section{Significance of the Asymmetry in Equivalent Elastic Modulus $\boldsymbol{E}$}

[28] Contrasting elastic properties across strike-slip faults are expected as they juxtapose different rock bodies on the opposite sides of faults. This has long been recognized. Reid [1910] observed at the beginning of last century an asymmetry in the coseismic motion of the 1906 San Francisco earthquake and stated that "this is probably in part due to the fact that the rocks on the western side are more rigid than those on the eastern side." Prescott and Yu [1986] noted an asymmetry in interseismic strain across the northern San Andreas fault near Point Reyes, and Lisowski et al. [1991] pointed out that lateral inhomogeneity could explain this asymmetry. They computed simple models assuming a ratio of 5 in the elastic parameter. They demonstrated further that the effect of a low-rigidity fault is to concentrate deformation within it. Li and Rice [1987, p. 11,546] proposed that the "the upper mantle to the SW of the San Andreas there could be too cool to deform readily and hence could move as an effectively rigid zone."
[29] Yet contrasts in seismic velocity across a fault do not usually exceed 1.35 [Ben-Zion and Andrews, 1998]. Because the elastic parameter varies approximately as the seismic velocity to the third power [see, e.g., Andrews and Ben-Zion, 1997], the maximum elastic parameter ratio expected is $\sim 2.5\left(1.35^{3}\right)$, not 10 as above. However, the Marmara fault closely follows the base of the northern margin south of the area where are sites MAER and SELP. As a result, there is a $4-6 \mathrm{~km}$ offset between the basement on both sides of the fault ( $2 \mathrm{~km}$ of water and $2-4 \mathrm{~km}$ of sediments). J. Rice (personal communication, 2002) pointed out that this vertical offset would account for a significant part of the asymmetry of elastic deformation observed. We conclude that part of the asymmetry comes from the offset in the level of the crustal rocks on both sides of the fault and part in different composition of the rocks. That rocks on both sides of the Main Marmara fault are different is suggested by the geology. This is because in the Marmara region, the northern branch of the North Anatolian fault [Sengör, 1979] follows closely a fundamental paleotectonic boundary between the "Palaeozoic of Istanbul" [Sengör and Yilmaz, 1981] or the Istanbul Zone [Görür et al., 1997] and the IntraPontide suture [Sengör and Yilmaz, 1981]. The Istanbul Zone consists of a multiply deformed continental massif detached from the southern margin of the Odessa shelf in the late Cretaceous as the Black Sea opened behind it. South of the Main Marmara fault lies a geologically young $20+\mathrm{km}$ wide $60 \mathrm{Ma}$ suture that is filled with a metapelitic matrix melange. To the north, a well-consoli- 


\section{MARMARA FAULT}

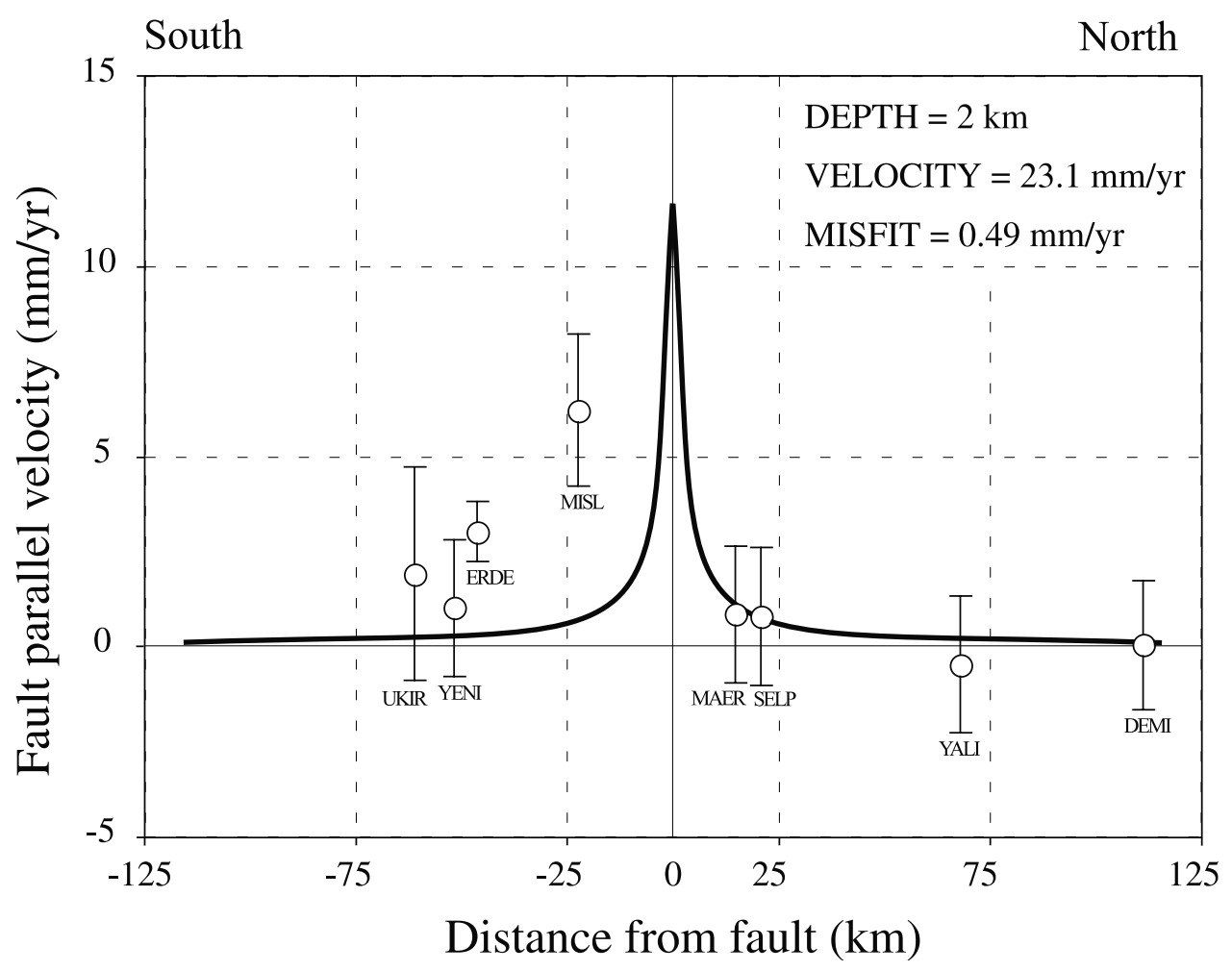

Figure 11. Same as Figure 10 but the actual position of the fault is imposed. The velocity on the fault that agrees with the rotation rate found in the inversion of Ganos fault is also imposed. Only the depth of locking is inverted. It is impossible to fit both the north and the south with the same parameters.

dated basement is present east of Buyukcekmece. To the west of Buyukcekmece, the basement is expected to be a Cretaceous subduction-accretion complex.

\section{Main Marmara Fault Branch Within the North Anatolian Fault Zone}

[30] The Main Marmara fault is part of the northwestward extension of the North Anatolian fault zone [Sengör, 1979]. Since 1939, the North Anatolian fault zone has been affected by a westward propagating series of large dextral earthquakes that ruptured a total length of about $1000 \mathrm{~km}$ between $40^{\circ} \mathrm{E}$ and $29^{\circ} \mathrm{E}$ (Figure 13) [Barka, 1996, 1999]. In a broad picture, the fault zone can be described as consisting of three arcs (in blue in Figure 13). The eastern one includes the 1939 rupture and the median one the ruptures from 1942 to 1967 . The western one, which we call the Marmara arc, has been ruptured in 1999 at its eastern extremity and in 1912 at its western one. The central Main Marmara fault portion is the only portion of the Marmara arc that is still unruptured. The motion along all three arcs is dextral strikeslip at the same velocity $(23 \mathrm{~mm} / \mathrm{yr}$ in the solution of McClusky et al. [2000]). The three arcs are included within a $100 \mathrm{~km}$ wide envelope formed by two small circles (in dashed black in Figure 13) about the Anatolia/Eurasia pole. Each arc makes an angle of $\sim 20^{\circ}$ with the next western one on which it overlaps in such a way that the fault zone keeps an approximately constant distance of about $100 \mathrm{~km}$ to the base of the Black Sea continental margin. This was already noted by Sengör [1979], Hubert-Ferrari [1998], and McClusky et al. [2000].

[31] Steckler and ten Brink [1986] have shown that for many continental margins a zone of minimum strength lies along the landward part of the margin. Melbourne and Helmberger [2001] have shown more recently that regionally maximum dextral strain rates in western North America are localized where the strong Pacific plate is juxtaposed to the weak continental North America. They suggest that the uppermost mantle modulates long-term, regional-scale continental margin deformation and evolution. Thus the progression of the fault appears to be guided by a double constraint: follow the zone of minimum strength and simultaneously follow a boundary that is as close as possible to a pure strike-slip fault. Both constraints tend to minimize the mechanical energy spent.

[32] The passage from one arc to the next one is critical because the overlapping segments keep their predominantly strike-slip character. The angular relationship between the two arcs leads to a kinematically unstable geometry and requires adjustment. Barka et al. [2000] have recently described the tectonics of the connection between the 1939 and the 1942-1943 ruptures. They found evidence for recent rearrangement of the fault system in the connection area. At least part of the adjustment is done by clockwise rotation of the block between the two arcs in the area of overlap as Tatar et al. [1995] have measured paleomagnetic rates of clockwise rotations in this overlap region in excess of $50^{\circ} / \mathrm{Myr}$. Similar fast rotations have 


\section{MARMARA FAULT}

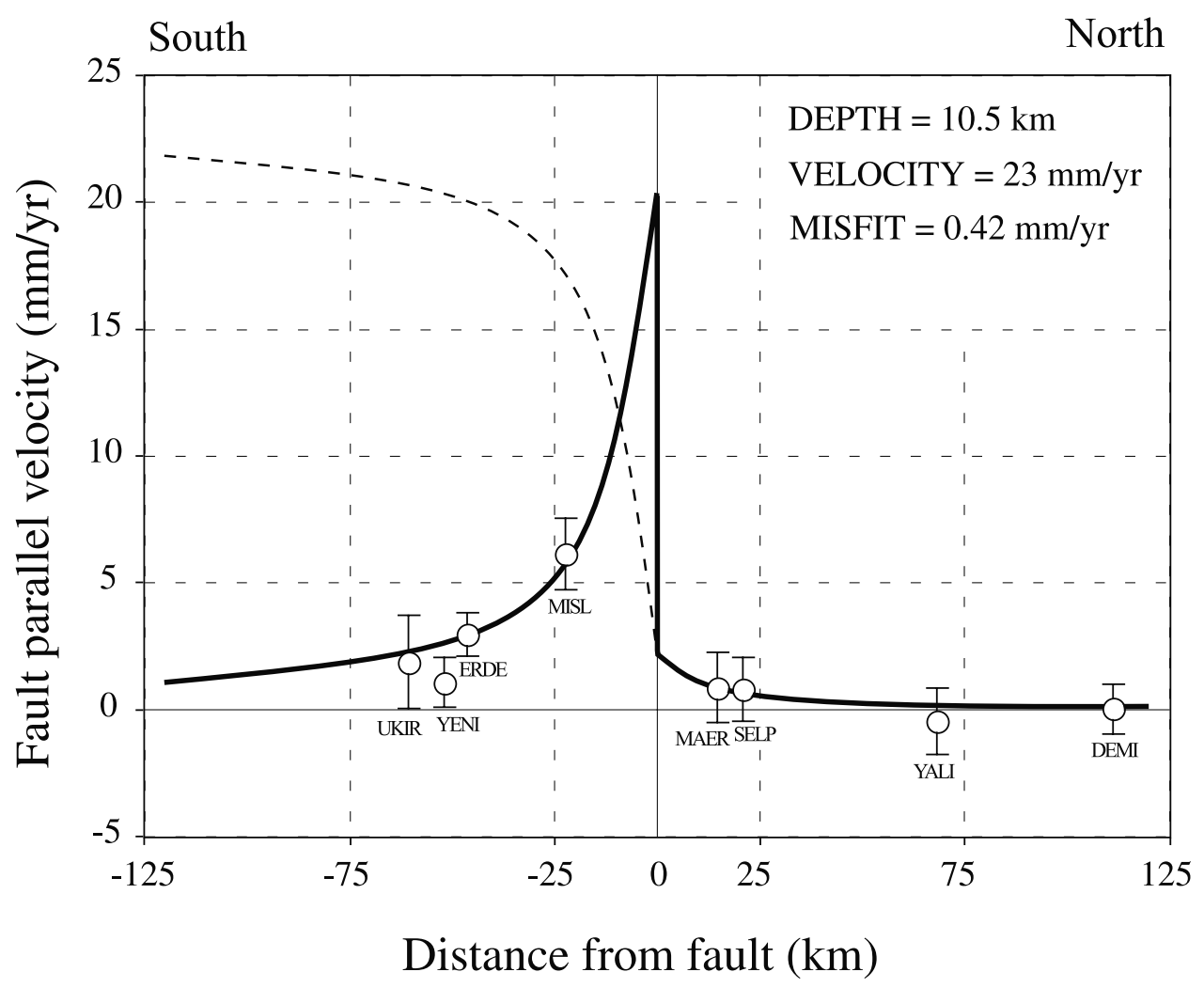

Figure 12. A coupled solution with inversion of locked depth and velocities. The locked depth is of course unique but the velocity may be different to the north and south subject to the condition that the sum of the velocities be equal to the fault velocity in Figure 11. We minimize the sum of the deviations between modeled and measured velocities on both sides. The fit is good on both sides. In addition to the elastic effect versus distance (solid line), we have shown the total velocity curve with respect to the north (dashed line). This curve illustrates that the axis of symmetry is displaced $10 \mathrm{~km}$ south of the actual fault.

been demonstrated in the so-called Almacik flake, at the junction between the second and third arcs, near $31^{\circ} \mathrm{E}$ [Saridubak et al., 1990; Sengör et al., 1985]. The 7.2 Duzce 1999 earthquake (1999b in Figure 13) and the eastern portion of the 7.4 Kocaeli 1999 earthquake (1999a) ruptured the northern boundary of the Almacik flake whereas the 1957 and 1967 earthquakes had ruptured the southern boundary (see Figure 13). At the scale of Figure 13, the large earthquake ruptures coincide with portions of faults that have a simple geometry and the limits between the large ruptures tend to coincide with the change in geometry (see also Table 1).

[33] This analysis demonstrates that within the context of the whole North Anatolian fault zone, the Marmara arc is closer to pure dextral strike-slip than the second and specially the third arcs. Compare the geometry of the two arcs with the Anatolian small circles in Figure 13 and in contrast see how the whole Marmara arc closely follows the same slip line of the Marmara block with respect to Eurasia in Figure 6. The only significant exception concerns the eastern Cinarcik basin (see Figure 1). There, the fault follows the northern margin along a length of $36 \mathrm{~km}$ with a $299^{\circ}$ trend, whereas the velocity vector from GPS is $23 \mathrm{~mm} / \mathrm{yr}$ to $272^{\circ}$. The $27^{\circ}$ obliquity between the fault and the motion should produce a normal component of $12 \mathrm{~mm} /$ yr and a dextral component of 20. Yet Le Pichon et al.
[2001] have seen no evidence of a large active extensional component along the fault at the foot of the northern margin. Rather, they find evidence for an active field of extensional faults to the south of the basin and parallel to it and for a N-S shortening field to the west of the basin where the Main Marmara fault turns $30^{\circ}$ and becomes pure strikeslip again (Figure 1). They argue that this is due to slip partitioning. A simplified kinematic model of this partitioning is given in Table 1 using a Cinarcik microblock. This microblock model produces pure dextral strike slip at $23 \mathrm{~mm} / \mathrm{yr}$ along the fault at the foot of the northern Cinarcik margin. Distension occurs at $10 \mathrm{~mm} / \mathrm{yr}$ in the $10^{\circ}$ direction within the southern extensional field. The shortening immediately south of the $30^{\circ}$ turn of the fault, south of Yesilkoy (Figure 1), results from overlap of the Cinarcik microblock over the western pure strike-slip area, as the microblock is transferred westward. Because the Cinarcik unit of the fault is convex southward, as demonstrated earlier, the motion of the Cinarcik microblock with respect to the Marmara block is a clockwise rotation, with an Euler pole $<100 \mathrm{~km}$ to the west (Table 1).

[34] The obvious question then is why the Sea of Marmara is a tectonic depression if it is not a pull apart. We do not try to discuss the geological history of the Sea of Marmara here. This will be done elsewhere. Rather, we wish to emphasize that the evidence presented by Le Pichon 


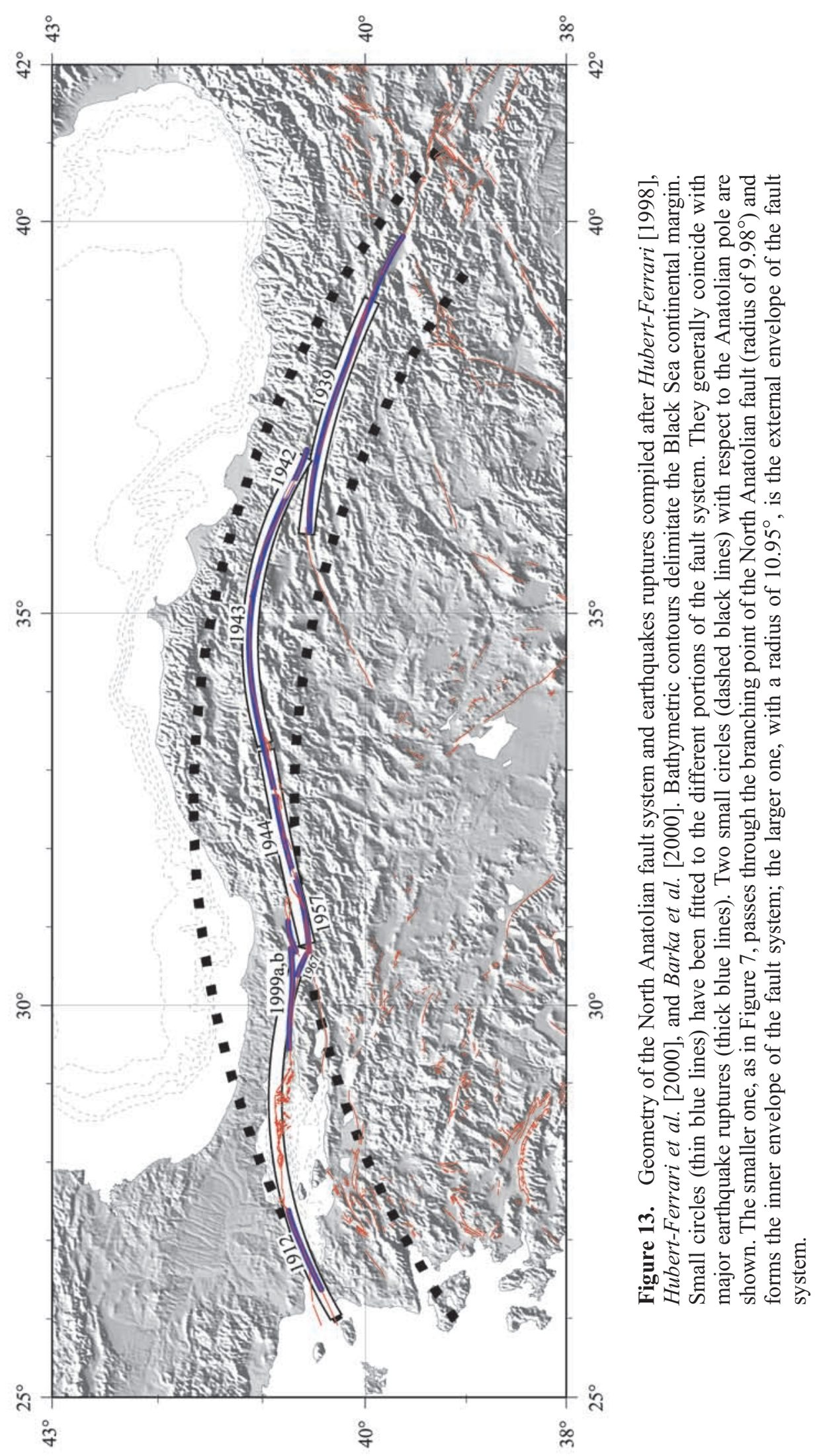


et al. [2001] indicates that the present trace of the Main Marmara fault is recent. The $4 \pm 1 \mathrm{~km}$ offset observed suggests that it reached its present configuration only 175,000 years ago (160,000 using the velocity of Meade et al. [2002]). Another argument is in favor of this conclusion. The configuration of the southern boundary of the Marmara block is still quite complex and has not yet reached the simple configuration of the fault on the northern boundary. Thus the total offset necessary to establish a mature fault trace has been reached to the north but not to the south as also pointed out by Sengör et al. [1985]. Yet the establishment of the present trace of the Main Marmara fault must be approximately contemporaneous to the formation of the Marmara block. The difference in maturity of the faults to the north and south of the Marmara block thus is not due to a difference in age. We attribute it to the fact that the velocities on the southern boundary are less than a third from the velocities on the northern boundary. Thus any accumulated offset to the south is less than a third of the northern accumulated offset. It is unfortunately not possible to estimate directly the amount of motion that has occurred on the north fault since the initiation of the Marmara block motion as it exists today, except that we know that it is larger than $4 \mathrm{~km}$. However, the rectilinearity of the fault suggests a fast propagation rate. The absence of change in the $4 \mathrm{~km}$ \pm 1 offset over $100 \mathrm{~km}$ confirms this fast propagation rate. The propagation rate had to be faster than $2 \mathrm{~km} / 1000$ years not to change by more than $1 \mathrm{~km}$ over $100 \mathrm{~km}$.

[35] Figure 13 illustrates nicely the probable kinematic situation prior to this Marmara block stage. If the Marmara block did not exist, then the Marmara area kinematically belonged to Anatolia. The motion vector along its northern boundary made an angle of $30^{\circ}$ to the east, decreasing to $23^{\circ}$ at the western extremity of the Gulf of Izmit, then to essentially zero along the western Ganos fault. The normal extensional component decreased from $13 \mathrm{~mm} / \mathrm{yr}$ to the west to zero to the east. The Ganos fault could function as a dextral strike-slip fault in this previous system while the Sea of Marmara coincided with a section of fault that was increasingly transtensional eastward. The progressive increase of the extensional component eastward may have been the cause for the increase in size of the sedimentary basins toward the east and the $250^{\circ}$ direction of slip expected there coincides rather well with the main direction of the Central and Western Highs (Figure 1). On the other hand, the extensional component should have continued to increase east of the Sea of Marmara but there is no evidence for extension east of $29^{\circ} 30^{\prime} \mathrm{E}$. The answer may lie in a clockwise rotation of the Armutlu block (identified in Figure 1), similar and probably concomitant with the rotation of the adjacent Almacik flake discussed above (see Figure 13). The rotations of the two blocks could possibly accommodate the transition from the second to the third arcs.

\section{Implications for Future Earthquakes Within the Marmara Seismic Gap}

[36] Since the recent 7.4 Kocaeli earthquake, the scientific community has reached a consensus concerning the large probability of rupture within the next few tens of years of the identified seismic gap between the 1999 Kocaeli rupture and the 1912 Ganos rupture [Hubert-Ferrari et al., 2000; Parsons et al., 2000]. However, there is no consensus on the nature of the expected earthquakes, their magnitude, and the rupture locations. The discussion of the future earthquakes is complicated by the difficulty of evaluating earlier large historical earthquakes believed to have occurred within the Sea of Marmara [Ambraseys and Finkel, 1995, 1990, 1991; Ambraseys and Jackson, 1998, 2000]. The most significant are the 1509 earthquake long considered [Ambraseys and Finkel, 1995, p. 37] as "one of the most destructive earthquakes of the last five centuries in the Mediterranean" [Ambraseys and Finkel, 1990, p. 171] "associated with source dimensions of at least $200 \mathrm{~km}$," the 18 th century sequence $(1719,1754$, May 1766, August 1766) and the 1894 earthquake. Recently, Ambraseys and Jackson [2000] reevaluated these historical data. This reevaluation led Ambraseys and Jackson [2000, p. F5] to state that there has been an "absence of large damaging earthquakes along the northern shore of the Sea of Marmara" since 1500 between Silivri and Tekirdag (see locations in Figure 1). As a result, they conclude that the western part of the Sea of Marmara has not been ruptured since at least 1500 . This contradicts the common sense interpretation that the August 1766 earthquake was triggered by the adjacent rupture of the May 1766 one [HubertFerrari et al., 2000]. In this case, 1766 would be the last year during which the whole Main Marmara fault would have broken. In the solution of Ambraseys and Jackson [2000], however, there is a gap of at least $100 \mathrm{~km}$ between the two ruptures.

[37] The kinematic analysis we have made in this paper enables us to state that $23 \mathrm{~mm} / \mathrm{yr}$ of pure dextral strike-slip motion occur along the $150 \mathrm{~km}$ Main Marmara fault. The microseismicity shows that the fault is active [Gurbuz et al., 2000] (see Figure 6). Ten earthquakes of magnitude larger than about 4.5 of the [Engdahl et al., 1998] catalog appear to be associated with this fault (see Figure 1). A 24 April 1988 magnitude 5 dextral strike-slip earthquake occurred halfway between the longitudes of MAER and SELP (see Figure 6) [Gurbuz et al., 2000]. These medium size earthquakes indicate that elastic deformation is accumulating there. This is confirmed by GPS studies: the Main Marmara fault accumulates elastic deformation, albeit in an asymmetrical way. It is consequently locked and this locking should lead to large earthquakes. What is then the explanation for the absence of large earthquakes there?

[38] Lisowski et al. [1991] pointed out that if the fault is within a low rigidity body, deformation will be concentrated within the low rigidity rocks. This is the case of the western Main Marmara fault. The simple model of asymmetry we have used predicts a decrease by a factor of 5 of the expected coseismic motion to the north of the northern Marmara margin and an increase by a factor of 2 to the south. In addition, the asymmetry would make the seismic source appear to be about 10-12 km farther south than it actually is. Furthermore, Andrews and Ben-Zion [1997] showed that if the fault is a material discontinuity interface, as is the case along the northern Marmara margin, the rupture will tend to occur as a narrow pulse that propagates in a wrinkle-like mode within the low rigidity material. Thus shear displacement during the rupture would be 
expected to be much larger on the Marmara side, and a large normal component of motion would be present there. One might also expect a focusing effect at both extremities of the western Main Marmara fault in the regions of YesilkoyIstanbul and in the region of Ganos (see Figure 1). We suggest that these combined effects might explain why macroseismic damage is often significant to the south but not to the north although the fault lies closer to the northern shore.

[39] If this hypothesis is correct, the gap in damage on the northwestern shore is not related to a gap in rupture and the two 1766 earthquake ruptures were contiguous. There is strong evidence that the August 1766 earthquake ruptured the Ganos fault and that the junction between the Ganos and Main Marmara faults stopped the 1912 earthquake. Thus the May 1766 earthquake probably ruptured the whole $150 \mathrm{~km}$ of the Main Marmara fault as both Ambraseys and Jackson [2000] and Parsons et al. [2000] show that this earthquake definitely ruptured the Cinarcik unit. The same reasoning can be applied to the 1509 earthquake: the intensities of damage observed on the northern shore of the Sea of Marmara become compatible with rupture of the entire Main Marmara fault [see Parsons et al., 2000, Figure 2]. Meade et al. [2002] also proposed that the 1509 and May 1766 earthquake broke the whole Main Marmara fault because their model decreases the expected moment for such a rupture by a factor of 2.3. The fact that the $30^{\circ}$ bend between the western unit and the Cinarcik unit of the Main Marmara fault did not stop the May 1766 and 1509 earthquakes should not surprise as a very similar bend did not stop the progression of the 1992 Landers earthquake rupture [Bouchon et al., 1998]. The expected moment of this future Marmara earthquake would be 7.6 as proposed by Le Pichon et al. [1999]. However, this estimate does not take into account the decrease in moment related to the decreased elastic modulus to the south. A better estimate would require modeling of the effects of such an earthquake.

[40] The only other place where we have identified a kinematically important active fault is the $30 \mathrm{~km}$ normal fault system to the southeast of the Cinarcik basin where the average extensional rate is $10 \mathrm{~mm} / \mathrm{yr}$. There, one might expect normal fault earthquakes of magnitude 7 if the repeat occurrence is also 250 years. The 1894 earthquake may have been one of these. The location and amplitude fit with those proposed by Parsons et al. [2000]. Of course, there may be other significant earthquakes along faults where the rate of loading is not kinematically detectable. And these most probably exist within the Sea of Marmara. However, we believe that we have identified in the Sea of Marmara the kinematically important faults where the repetition rate of large earthquakes is of the order of only 250 years to 500 years as along the main part of the North Anatolian fault [Stein et al., 1997].

\section{Conclusion}

[41] Building on the results of Le Pichon et al. [2001] and Meade et al. [2002], we show the existence of a Marmara block delimited to the north by the northern branch of the North Anatolian fault. We derive from GPS data the kinematics of this block. This branch that crosses the Sea of Marmara is close to pure dextral strike-slip at a rate of 23 $\mathrm{mm} / \mathrm{yr}$ on its whole length. The short Cinarcik section, in the eastern Sea of Marmara, is the only one where a significant extensional component is expected. We present a simple kinematic model that accounts for the slip partitioning observed by Le Pichon et al. [2001] there, with $8-10 \mathrm{~mm} / \mathrm{yr}$ of extension to the south of the basin and 23 $\mathrm{mm} / \mathrm{yr}$ of dextral strike slip along the northern Cinarcik margin.

[42] Using the GPS data, we demonstrate the existence of asymmetric elastic loading along the Main Marmara fault. The elastic loading is 10 times less to the north of the fault than to the south. We attribute this asymmetry in part to a reduced effective elastic parameter within the crust of the Marmara basin and in part to the $4-6 \mathrm{~km}$ vertical offset of the basement. We propose that this asymmetry may have important implications for the analysis of historical earthquakes and the effects of future earthquakes within the Marmara seismic gap. This is because it may explain the observation of Ambraseys and Jackson [2000] that damages from large earthquakes are not found along the northern shore of the Sea of Marmara since 1500 between Silivri and Tekirdag (see locations in Figure 1).

[43] We propose that the most likely scenario for the expected future large earthquake is one that would probably resemble that of the May 1766 earthquake with rupture of the whole Main Marmara fault. We also propose that the partitioning in the Cinarcik basin may produce magnitude 7 normal faulting earthquakes if their repetition time is $\sim 250$ years. The 1896 earthquake may have been one of these normal fault earthquakes.

[44] We discuss the place and significance of the Marmara fault branch in the evolution of the North Anatolian fault. We present evidence that the Marmara block is probably geologically very young (much less than $1 \mathrm{Myr}$ old). In that case, prior to its formation, it was part of the North Anatolian block. At this time the Ganos fault was already a dextral strike-slip fault but the fault system in the Sea of Marmara would have been affected by an extensional component increasing toward the east that would be the cause of the increasing size of the sedimentary basins eastward. The absence of extension east of the Sea of Marmara can be explained by a clockwise rotation of the Armutlu peninsula.

[45] Acknowledgments. We thank Robert Reilinger, Brendan Meade, and Simon McClusky for communicating their preprint and the data on which it is based prior to publication and for making a critical review of a first version of this paper. We thank A. Cisternas and H. Haessler for communicating the microearthquakes file and Mustafa Aktar for communicating the fault plane solution and location of the 28 February 20024.1 Marmara earthquake. Discussions with J. Rice, W. Thatcher, Pierre Henry, Raul Madariaga, Alan Levander, Jean-Claude de Bremaecker, and Kurt Feigl were useful. We thank Emin Demirbag and Charlotte Nielsen for help with the figures. CNRS, Collège de France, and Tubitak supported this work.

\section{References}

Ambraseys, N. N., and C. F. Finkel, The Marmara Sea earthquake of 1509, Terra Nova, 2, 167-174, 1990.

Ambraseys, N. N., and C. F. Finkel, Long-term seismicity of Istanbul and the Marmara Sea region, Terra Nova, 3, 527-539, 1991.

Ambraseys, N., and C. F. Finkel, The Seismicity of Turkey and Adjacent Areas, a Historical Review, 1500-1800, 240 pp., Eren, Istanbul, 1995.

Ambraseys, N. N., and J. A. Jackson, Faulting associated with historical and recent earthquakes in the eastern Mediterranean region, Geophys. J. Int., 133, 390-406, 1998. 
Ambraseys, N. N., and J. A. Jackson, Seismicity of the Sea of Marmara (Turkey) since 1509, Geophys. J. Int., 141, F1-F6, 2000.

Andrews, D. J., and Y. Ben-Zion, Wrinkle-like pulse on a fault between different materials, J. Geophys. Res., 102, 553-5571, 1997.

Armijo, R., B. Meyer, A. Hubert, and A. Barka, Westward propagation of the North Anatolian fault into the northern Aegean: Timing and kinematics, Geology, 27, 267-270, 1999.

Armijo, R., B. Meyer, S. Navarro, and G. King, Slip partioning in the Sea of Marmara pull-apart: A clue to propagation processes of the North Anatolian fault, Terra Nova, 14, 80-86, 2002.

Barka, A., Slip distribution along the North Anatolian fault associated with large earthquakes of the period 1939 to 1967, Bull. Seismol. Soc. Am., 86, $1238-1254,1996$.

Barka, A., The 17 August 1999 Izmit earthquake, Science, 285, $1858-$ 1859, 1999.

Barka, A. A., and K. Kadinsky-Cade, Strike-slip fault geometry in Turkey and its influence on earthquake activity, Tectonics, 7, 663-684, 1988.

Barka, A., H. S. Akyuz, H. A. Cohen, and F. Watchorn, Tectonic evolution of the Niksar and Tasova-Erbaa pull-apart basins, North Anatolian fault zone: Their significance for the motion of the Anatolian block, Tectonophysics, 322, 243-264, 2000.

Ben-Zion, Y., and D. J. Andrews, Properties and implications of dynamic rupture along a material interface, Bull. Seismol. Soc. Am., 88, $1085-$ 1094, 1998.

Bouchon, M., M. Campillo, and F. Cotton, Stress field associated with the rupture of the 1992 Landers, California earthquake and its implications concerning the fault strength at the onset of the earthquake, J. Geophys. Res., 103, 21,091-21,097, 1998.

Chinnery, M. A., The deformation of the ground around surface faults, Bull. Seismol. Soc. Am., 355-372, 1961.

Demirbag, E., C. Rangin, X. Le Pichon, and A. M. Celal Sengor, Investigation of the tectonics of the Main Marmara fault by means of deep towed seismic data, Tectonophysics, 361, 1-19, 2003.

Engdahl, E. R., R. Van der Hilst, and R. Buland, Global teleseismic earthquake relocatiosn with improved travel times and procedures for depth determination, Bull. Seismol. Soc. Am., 88, 722-743, 1998.

Görür, N., O. Monod, A. I. Okay, A. M. C. Sengör, O. Tüysüz, E. Yigitbas, M. Sakinç, and R. Akkök, Palaeogeographic and tectonic position of the Carboniferous rocks of the western Pontides (Turkey) in the frame of the Variscan Belt, Bull. Soc. Géol. Fr., 168, 197-205, 1997.

Gurbuz, C., et al., The seismotectonics of the Marmara region (Turkey): Results from a microseismic experiment, Tectonophysics, 316, 1-17, 2000.

Halbach, P., I. Kuscu, T. Kuhn, A. Pekdeger, and R. Seifert, Methane in sediments of the deep Marmara Sea and its relation to local tectonic structures (abstract), in NATO advanced Research Seminar: Integration of Earth Sciences Research on the 1999 Turkish and Greek Earthquakes and Needs for Future Cooperative Research, edited by N. Gorur, p. 74, Tubitak, Istanbul, 2000

Hubert-Ferrari, A., La faille nord-anatolienne, Univ. Paris 7, Paris, 1998.

Hubert-Ferrari, A., A. Barka, E. Jacques, S. Nalbant, B. Meyer, R. Armijo, P. Tapponnier, and G. P. King, Seismic hazard in the Marmara sea region following the 17 August 1999 Izmit earthquake, Nature, 404, 269-273, 2000.

Imren, C., X. Le Pichon, C. Rangin, E. Demirbag, B. Ecevitoglu, and N. Gorur, The North Anatolian fault within the Sea of Marmara: A new interpretation based on multi-channel seismic and multi-beam bathymetry data, Earth Planet. Sci. Lett., 186, 143-158, 2001.

Le Pichon, X., N. Chamot-Rooke, R. Noomen, and G. Veis, Cinématique de l'Anatolie-Egée par rapport à l'Europe à partir d'une combinaison des mesures de triangulation géodésique sur 80 ans aux mesures SLR récentes, C. R. Acad. Sci., 318, 1387-1393, 1994.

Le Pichon, X., N. Chamot-Rooke, S. Lallemant, R. Noomen, and G. Veis, Geodetic determination of the kinematics of central Greece with respect to Europe: Implications for eastern Mediterranean tectonics, J. Geophys. Res., 100, 12,675-12,690, 1995.

Le Pichon, X., T. Taymaz, and A. M. C. Sengör, The Marmara Fault and the future Istanbul earthquake, in International Conference on the Kocaeli Earthquake, 17 August 1999, edited by M. Karaca and D. N. Ural, pp. 41-54, Istanbul Tech. Univ. Press, Istanbul, 1999.

Le Pichon, X., A. M. C. Sengor, E. Demirbag, C. Rangin, C. Imren, R. Armijo, N. Gorur, N. Cagatay, B. Mercier de Lépinay, B. Meyer, R. Saatcilar, and B. Tok, The active Main Marmara fault, Earth Planet. Sci. Lett., 192, 595-616, 2001.

Li, V. C., and J. R. Rice, Crustal deformation in great California earthquake cycles, J. Geophys. Res., 92, 11,533-11,551, 1987.
Lisowski, M., J. C. Savage, and W. H. Prescott, The velocity field along the San Andreas Fault in central and southern California, J. Geophys. Res., 96, 8369-8389, 1991.

McClusky, S., et al., Global Positioning System constraints on plate kinematics and dynamics in the eastern Mediterranean and Caucasus, J. Geophys. Res., 105, 5695-5719, 2000.

Meade, B. J., B. H. Hager, S. C. McClusky, R. Reilinger, S. Ergintav, O. Lenk, A. Barka, and H. Ozener, Estimates of seismic potential in the Marmara Sea region from block models of secular deformation constrained by Global Positioning System measurements, Bull. Seismol. Soc. Am., 92, 208-215, 2002.

Melbourne, T., and D. Helmberger, Mantle control of plate boundary deformation, Geophys. Res. Lett., 28, 4003-4006, 2001.

Okay, A. I., E. Demirbag, H. Kurt, N. Okay, and I. Kuscu, An active, deep marine strike-slip basin along the North Anatolian fault in Turkey, Tectonics, 18, 129-147, 1999.

Parsons, T., S. Toda, R. S. Stein, A. Barka, and J. H. Dieterich, Heightened odds of large earthquakes near Istanbul: An interaction-based probability calculation, Science, 288, 661-665, 2000.

Prescott, W. H., and S. B. Yu, Geodetic measurements of horizontal deformation in the northern San Francisco Bay region, California, J. Geophys. Res., 91, 7475-7484, 1986.

Reid, H. F., The mechanics of the earthquake, in The California Earthquake of April 18, 1906, Report of the State Earthquake Investigation Commission, p. 192, Carnegie Inst. of Washington, Washington, D. C., 1910.

Reilinger, R. E., S. C. McClusky, M. B. Oral, R. W. King, and M. N. Toksoz, Global Positioning System measurements of present-day crustal movements in the Arabia-Africa-Eurasia plate collision zone, J. Geophys. Res., 102, 9983-9999, 1997.

Saridubak, M., M. Sanver, A. M. C. Sengor, and N. Gorur, Paleomagnetic evidence for substantial roation of the Almacik flake within the North Anatolian fault zone, NW Turkey, Geophys. J. Int., 102, 563-568, 1990.

Savage, J. C., Equivalent strike-slip earthquake cycles in half-space and lithosphere-asthenosphere earth models, J. Geophys. Res., 95, 4873$4879,1990$.

Savage, J. C., and R. O. Burford, Geodetic determination of relative plate motion in central California, J. Geophys. Res., 78, 832-845, 1973.

Sengör, A. M. C., The North Anatolian transform fault: Its age, offset and tectonic significance, J. Geol. Soc. London, 136, 269-282, 1979.

Sengör, A. M. C., and Y. Yilmaz, Tethyan evolution of Turkey: A plate tectonic approach, Tectonophysics, 75, 181-241, 1981.

Sengör, A. M. C., N. Görür, and F. Saroglu, Strike-slip faulting and related basin formation in zones of tectonic escape: Turkey as a case study, in Strike-Slip Deformation, Basin Formation and Sedimentation, edited by K. T. Biddle and N. Christie-Blick, Spec. Publ. Soc. Econ. Paleontol. Mineral., 37, 227-264, 1985.

Steckler, M. S., and U. S. ten Brink, Lithospheric strength variations as a control on new plate boundaries: Examples from the Arabian plate, Earth Planet. Sci. Lett., 79, 120-132, 1986.

Stein, R. S., A. Barka, and J. Dietrich, Progressive earthquake failure on the North Anatolian fault since 1939 by stress triggering, Geophys. J. Int., 128, 594-604, 1997.

Straub, C. S., Recent crustal deformation and strain accumulation in the Marmara sea region, NW Anatolia, inferred from GPS measurements, thesis, 123 pp., ETH, Zurich, 1996.

Straub, C., and H. G. Kahle, Global positioning estimates of crustal deformation in the Marmara Sea region, northwestern Anatolia, Earth Planet. Sci. Lett., 121, 495-502, 1994.

Tatar, O., J. D. A. Piper, R. G. Park, and H. Gursoy, Paleomagnetic study of block rotations in the Niksar overlap region of the North Anatolian fault zone, central Turkey, Tectonophysics, 244, 251-266, 1995.

Tchalenko, J. S., Similarities between shear zones of different magnitudes, Geol. Soc. Am. Bull., 81, 1625-1640, 1970.

Tuyusuz, O., A. Barka, and E. Yigitbas, Geology of the Saros graben and its implications for the evolution of the North Anatolian fault in the Ganossaros region, northwestern Turkey, Tectonophysics, 293, 105-126, 1998.

Weertman, J., and J. R. Weertman, Elementary Dislocation Theory, 213 pp., Macmillan, Old Tappan, N. J., 1964.

N. Chamot-Rooke, X. Le Pichon, and C. Rangin, UMR 8538, CNRS, Ecole Normale Supérieure, 24 rue Lhomond, F-75231 Paris Cedex 05, France. (rooke@geologie.ens.fr; lepichon@geologie.ens.fr; rangin@geologie. ens.fr)

A. M. C. Sengör, Istanbul Technical University, Department of Geology, Maslak, 80626 Istanbul, Turkey. (sengor@itu.edu.tr) 